American Journal of Infectious Diseases 5 (3): 231-258, 2009

ISSN 1553-6203

(C) 2009 Science Publications

\title{
Molecular Mechanisms of Neurodegenerative Diseases Induced by Human Retroviruses: A Review
}

\author{
${ }^{1}$ Bryan P. Irish, ${ }^{1}$ Zafar K. Khan, ${ }^{1}$ Pooja Jain, ${ }^{1}$ Michael R. Nonnemacher, ${ }^{1}$ Vanessa Pirrone, \\ ${ }^{1}$ Saifur Rahman, ${ }^{2}$ Nirmala Rajagopalan, ${ }^{2}$ Joyce B. Suchitra, ${ }^{3}$ Kate Mostoller and ${ }^{1}$ Brian Wigdahl \\ ${ }^{1}$ Department of Microbiology and Immunology, Center for Molecular Virology and Neuroimmunology, \\ Center for Molecular Therapeutics and Resistance, Center for International Medicine, \\ Institute for Molecular Medicine and Infectious Disease, \\ Drexel University College of Medicine, Philadelphia, Pennsylvania 19129, USA \\ ${ }^{2}$ Freedom Foundation, 180 Henur Cross, Bangalore, India \\ ${ }^{3}$ Department of Microbiology and Immunology, Pennsylvania State University, \\ College of Medicine, 500 University Drive, Hershey, PA 17033
}

\begin{abstract}
Problem statement: Infection with retroviruses such as human immunodeficiency virus type 1 (HIV-1) and human T cell leukemia virus type 1 (HTLV-1) have been shown to lead to neurodegenerative diseases such as HIV-associated dementia (HAD) or neuroAIDS and HTLV-1Associated Myelopathy/Tropical Spastic Paraparesis (HAM/TSP), respectively. Approach: HIV-1induced neurologic disease is associated with an influx of HIV-infected monocytic cells across the blood-brain barrier. Following neuroinvasion, HIV-1 and viral proteins, in addition to cellular mediators released from infected and uninfected cells participate in astrocytic and neuronal dysregulation, leading to mild to severe neurocognitive disorders. Results: The molecular architecture of viral regulatory components including the Long Terminal Repeat (LTR), genes encoding the viral proteins Tat, Vpr and Nef as well as the envelope gene encoding gp120 and gp41 have been implicated in 'indirect' mechanisms of neuronal injury, mechanisms which are likely responsible for the majority of CNS damage induced by HIV-1 infection. The neuropathogenesis of HAM/TSP is linked, in part, with both intra-and extracellular effectors functions of the viral transactivator protein Tax and likely other viral proteins. Tax is traditionally known to localize in the nucleus of infected cells serving as a regulator of both viral and cellular gene expression. Conclusion/Recommendations: However, recent evidence has suggested that Tax may also accumulate in the cytoplasm and be released from the infected cell through regulated cellular secretion processes. Once in the extracellular environment, Tax may cause functional alterations in cells of the peripheral blood, lymphoid organs and the central nervous system. These extracellular biological activities of Tax are likely very relevant to the neuropathogenesis of HTLV-1 and represent attractive targets for therapeutic intervention.
\end{abstract}

Key words: HIV-1, HTLV-1, neuropathogenesis, viral proteins

\section{INTRODUCTION}

Human Immunodeficiency Virus type 1 (HIV-1) and Human T cell Leukemia Virus type 1 (HTLV-1) both belong to the retroviridae family of viruses. These two retroviruses by definition infect cells as RNA genomes and utilize viral encoded reverse transcriptase to synthesize a DNA copy of the genome to integrate into the host cell, chromosomal material thereby allowing them to utilize the host cell transcriptional machinery to synthesize components necessary for viral replication. In the case of both of these viruses, this integration ultimately results in productive viral replication that can under certain circumstances lead to an immunodeficiency marked by depletion of $\mathrm{CD}^{+}$ $\mathrm{T}$ cells and neurodegenerative diseases such as HIVAssociated Dementia (HAD) or neuroAIDS and HTLV-1-Associated Myelopathy/Tropical Spastic Paraparesis (HAM/TSP), respectively. In the case of HTLV-1, the integration event may also initiate a series of molecular and signaling events that leads to oncogenic processes within the $\mathrm{CD}^{+} \mathrm{T}$ cell

Corresponding Author: Brian Wigdahl, Department of Microbiology and Immunology,

Drexel University College of Medicine, 2900 Queen Lane, Philadelphia, PA 19129

Fax: (215) 848-2271 
compartment leading to malignancy within this critical immune cell population. Interestingly, these two disease processes share some similarity in that the resulting neurodegeneration is caused at least in part by (1) a dysregulation of inflammatory cytokines and chemokines, (2) recruitment of immune cells to the CNS albeit monocyte-macrophages in HIV-1 and T cells in HTLV-1 and (3) functional properties of viral transactivator proteins, Tat in the case of HIV-1 and Tax with HTLV-1-induced neurologic disease. In both of these retroviral-induced neurologic diseases, the shared mechanistic processes lead to devastating and progressive neurodegenerative consequences. In addition, both diseases have unique qualities. HIV-1 also involves other viral proteins such as Viral protein $\mathrm{R}$ (Vpr), Nef and the envelope proteins gp120 and gp41, all of which can be secreted and have been shown to have neurotoxic properties. HTLV-1 on the other hand, has been shown to involve gp46-specific antibodies directed against a number of cellular determinants. This review will provide an overview of the mechanisms of both HIV-1 and HTLV-1 neurodegeneration providing the current knowledge on the similarities and differences of these mechanisms.

Overview of HIV-1-associated neurologic disease: HIV-1 infection, in addition to resulting in the eventual destruction of the host immune system, may induce the establishment of a spectrum of neurologic disorders including severe dementia. Opportunistic infections resulting from Acquired Immunodeficiency Syndrome (AIDS) may affect the Central Nervous System (CNS), however, HIV-1 itself is also able to induce neuropathology $y^{[1-3]}$. Conditions directly induced by HIV-1 include peripheral neuropathies, vacuolar myelopathies, as well as a devastating cognitive and motor disorder known as HIV-Associated Dementia (HAD) ${ }^{[4-7]}$. With the advent of combination AntiRetroviral Therapy (cART), a mild, more subtle form of CNS dysfunction termed Minor Cognitive Motor Disorder (MCMD) has been described ${ }^{[5,7]}$. MCMD is characterized by a memory loss, decreased computational ability and much less pronounced higher cortical functions ${ }^{[8]}$. It has been suggested that $\sim 10 \%$ of adults infected with HIV-1 suffer from HAD and that the prevalence of individuals with MCMD may be much higher, possibly approaching $30 \%$ of the HIV-1positive population ${ }^{[7]}$. The clinical presentation of MCMD is associated with neuropathogical alterations characteristic of HIV encephalitis (HIVE) and this syndrome is associated with a poorer general prognosis for HIV-1-infected patients.
It is widely accepted that HIV-1 neuroinvasion occurs via transmigration of infected cells of the monocyte-macrophage lineage from the peripheral circulation, across the Blood-Brain Barrier (BBB) and into the CNS. Importantly, although macrophages and microglia are the only cells in the brain to be productively infected by $\mathrm{HIV}-1$, neuronal injury and apoptotic death occurs as a result of HIV-1 infection of the $\mathrm{CNS}^{[9,10]}$. The activation of the monocytic cells in the brain due to infection by HIV-1, viral proteins, or inflammatory mediators generated by the host in response to viral infection seemingly results in the release of neurotoxic viral factors which ultimately lead to astrocytic and neuronal dysfunction, thus driving neuropathogenesis and the establishment of $\mathrm{HAD}^{[11]}$. Additionally, viral proteins are also likely directly involved in neuronal damage and death. Neurotoxic viral proteins like Tat and gp120 are known to excessively stimulate neurons, resulting in excitotoxicity and the loss of critical cellular processes in a way corresponding to other neurodegenerative diseases ${ }^{[1,3,9,12-14]}$.

HIV-1 replication and the long terminal repeat: The initiating step of the HIV-1 lifecycle within an infected host involves a high-affinity interaction between the HIV-1 envelope (env) glycoprotein gp120 and the CD4 antigen expressed on target cells including $\mathrm{T}_{\mathrm{H}}$ cells and cells of the monocyte-macrophage lineage ${ }^{[15,16]}$. Viral attachment and subsequent entry into the target cell is then facilitated by the aid of an interaction between the HIV-1 env glycoprotein gp41 and either the chemokine receptor CXCR4 or CCR5, which are predominately expressed on the surface of $\mathrm{T}$ cells and mononuclear phagocytes, respectively ${ }^{[15,16]}$. The determination that CXCR4 and CCR5 function as coreceptors for HIV-1 attachment and entry into target cells led to a generalized but not entirely comprehensive understanding as to why some HIV-1 strains preferentially infect $\mathrm{T}$ cells, while others seem to prefer macrophages or both cell populations ${ }^{[15,16]}$. Once HIV-1 has gained entry into a target cell, its double-stranded RNA genome is reverse transcribed by the viral enzyme Reverse Transcriptase (RT), an RNA-dependent DNA polymerase. This process results in the formation of viral cDNA, which is subsequently integrated into the host's chromosomal DNA by the viral enzyme integrase. The integrated viral genome is referred to as a provirus, which is subsequently transcribed by the host enzyme RNA polymerase II (pol II) resulting in a polycistronic RNA message that is multiply spliced prior to translation. The translated viral proteins combined with two copies of the complete HIV-1 RNA genome allow for the 
formation of new viral particles, or virions able to infect adjacent cells within the host ${ }^{[17-27]}$.

The process of transcription from proviral DNA is driven by the viral promoter region or Long Terminal Repeat (LTR), a duplicated $\sim 640$ bp DNA region located at the 5' and 3' ends of the proviral genome resulting from the mechanism of reverse transcription ${ }^{[28]}$. HIV-1 transcription is modulated in part by interaction of the LTR with various host factors including members of the CCAAT/Enhancer Binding Protein family (C/EBP), the Specificity protein (Sp) family and Nuclear Factor-kappa B (NF-KB) isoforms, all of which bind to specific cis-acting elements within the HIV-1 LTR facilitating viral gene expression ${ }^{[29-38]}$. The HIV-1 LTR is also known to interact with viral factors including the trans-activating protein Tat and the accessory protein viral protein $\mathrm{R}(\mathrm{Vpr})$, factors which enable expression of viral gene products within multiple host cell populations under selected biological conditions $^{[32,39-41]}$.

HIV-1 Vpr has been shown to interact directly with the LTR. Electophorectic Mobility Shift (EMS) analyses have demonstrated an association with LTR sequences including C/EBP site I, the promoter-distal $\mathrm{NF}-\mathrm{KB}$ site, as well as the upstream ATF-CREB binding site ${ }^{[33,39]}$. This interaction between the LTR and $\mathrm{Vpr}$ was found to be sequence-specific with respect to C/EBP site $\mathrm{I}^{[39]}$, with $\mathrm{Vpr}$ preferentially binding a $3 \mathrm{~T}$ (C-to-T change at nucleotide position 3) C/EBP site I variant, which is known to bind C/EBP factors with low affinity $^{[33]}$. Importantly, affinity of $\mathrm{Vpr}$ for C/EBP binding site sequence variants within the HIV-1 LTR have been correlated to HAD, with the observation that C/EBP binding site variants which bind $\mathrm{Vpr}$ at high affinity being more prevalent in proviruses derived from brain tissue of autopsied dementia victims ${ }^{[39]}$.

HIV-1 transcription involves an early, Tatindependent and a late, Tat-dependent phase and transactivation of the viral genome is a critical step in the viral replication cycle ${ }^{[42]}$. The presence of Tat has been shown to increase LTR-mediated transcriptional activity by several hundred-fold and in the absence of Tat, viral replication falls to nearly undetectable levels $s^{[43-45]}$. Tat is a unique transcription factor in that it binds to the "UCU" bulge of the Transactivation Response Element (TAR), a cis-acting RNA enhancer element contained within the 5 ' end of all viral transcripts ${ }^{[42,46]}$. The interaction of HIV-1 Tat with TAR RNA increases viral transcription and elongation ${ }^{[47,48]}$. Specifically, HIV-1 Tat is known to promote the binding of pTEF-b (cyclin T1 and cdk9) to the TAR region located within the viral promoter, which is immediately downstream of the transcriptional initiation site. The interaction of Tat with pTEF-b and the TAR element results in hyperphosphorylation of the C-terminal domain and subsequent increased processivity of RNA polymerase II (pol II) ${ }^{[47]}$. Additionally, recent evidence has suggested that HIV-1 Tat may also be involved with the formation of the transcriptional preinitiation complex ${ }^{[47]}$. In addition to the HIV-1 LTR, Tat is known to upregulate several other viral as well as cellular genes. Within the CNS, Tat has been shown to stimulate HIV-1 LTR-mediated viral gene expression in the absence of the TAR region $^{[49]}$, an activity that may result from its ability to enhance the activity of cytokines like TNF- $\alpha^{[50]}$. TNF- $\alpha$ also has the ability to activate the HIV-1 LTR via activation of cytoplasmic NF- $\mathrm{KB}^{[50-52]}$ and this positive feedback mechanism may lead to constitutive TNF- $\alpha$ expression within HIV-1-infected cells.

The molecular diversity of HIV-1 is a key mediator of viral replication and fitness ${ }^{[39,53]}$ and sequence variation within Tat appears to influence its effects on HIV-1 LTR activity ${ }^{[54]}$. Studies have demonstrated tat sequence heterogeneity among brain-derived HIV-1 clones from patients with $\operatorname{AIDS}^{[55,56]}$ and while phylogenetic analyses of tat sequences have not revealed clustering among individual clinical groups, genetic diversity has been shown to be greatest among HAD patients ${ }^{[5]}$. Therefore, sequence variation within Tat likely impacts viral replication and possibly host responses to viral infection ${ }^{[57,58]}$. A recent study involving astrocytic and monocytoid cells cotransfected with tat clones derived from Non-Demented (ND) and demented (HAD) AIDS patients and varying LTR constructs revealed a decrease in Tat-mediated LTR transactivation ${ }^{[59]}$. Interestingly, both brainderived HAD and ND tat constructs induced expression of MCP-1 and IL-1 $\beta$ and microarray analysis revealed that upregulation of several host genes, including an enzyme involved in mediating heparan sulphate synthesis, which has been shown to be upregulated in the brains of HAD patients ${ }^{[59]}$. These studies suggest that mutations within the tat gene may result in neuropathogenic effects leading to the development of HAD that are independent of its ability to transactivate the HIV-1 LTR ${ }^{[59]}$.

The role of HIV-1 proteins in neurodegenerative disease: The mechanism by which HIV-1 infection induces neuronal damage and subsequent motor and neurocognitive impairment is a controversial subject, however it is generally accepted that HIV-1 does directly infect neurons to a limited extent ${ }^{[6]}$; although HIV-1 infection of neurons is not considered an important component of the etiology of 
neurodegenerative disease. HIV-1-associated neuropathology appears to be, in large part, due to neurotoxic viral proteins released into the extracellular environment by infected cells ${ }^{[60]}$. There is evidence suggesting a role for multiple HIV-1 proteins in CNS deregulation and neuronal injury including Tat, $\mathrm{Vpr}$, Nef and the Env proteins 120 and gp41 $1^{[6]}$. These observations have lead to the formulation of two primary theories for how HIV-1 infection results in neuropathology, the 'direct injury' theory and the 'indirect' or 'bystander effect' theory ${ }^{[61]}$. Clearly, the two theories proposed to explain the HIV-1-induced neuronal damage are by no means mutually exclusive and studies have demonstrated a role for both, however the 'indirect' mechanism appears to be the predominate means of neurodegenerative disease since the number of HIV-1-infected cells within the CNS does not always correlative with the extent of CNS pathology ${ }^{[3,10,62]}$.
The HIV-1 envelope proteins 120 and gp41: Several studies have provided evidence for both a direct and indirect role for gp 120 in neuronal injury and death ${ }^{[63-}$ ${ }^{65]}$. HIV-1 gp120 has been shown to induce neuronal apoptosis by interacting with chemokine receptors, CC-chemokine receptor 5 (CCR5) and CXCchemokine receptor 4 (CXCR4), expressed on the surface of neurons and glial cells ${ }^{[6,66]}$ (Fig. 1). Additionally, several studies have shown gp120mediated neuronal apoptosis occurs through interaction with the seven-transmembrane chemokine receptor CXCR4 ${ }^{[67-71]}$. Binding of gp120 to CCR5 and CXCR4 activates intracellular signal transduction pathways that mediate neuronal apoptosis ${ }^{[66,72,73]}$. Several studies have shown that gp120 disrupts calcium homeostasis in neurons and induces disruption of mitochondrial membrane integrity leading to release of cytochrome $\mathrm{c}$ and activation of caspases and endonucleases ${ }^{[73-75]}$.

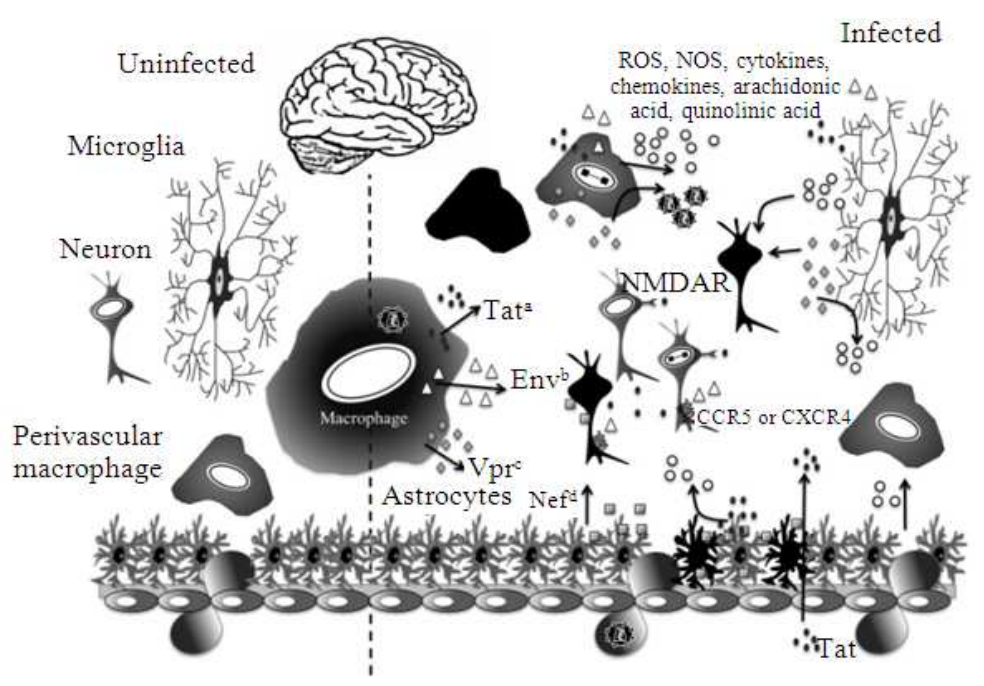

Fig. 1: Mechanism of HIV-1-induced neurodegeneration. Neurodegeneration caused by HIV-1 infection is the result of both direct infection of cells, as well as the release of HIV-1 proteins that cause additional neurodegeneration. Infected perivascular macrophages and microglia, in addition to producing more infectious virus, can also release these viral proteins. These proteins include Tat, Env (120 and gp41) and Vpr; (a) Tat (represented as $\bullet$ ) exhibits effects on both infected and uninfected cells, because secreted Tat can be taken up by neighboring cells. Tat has been demonstrated to play a role in oxidative stress-dependent apoptosis of neurons (represented by black cells). It has also been shown that Tat can cause excitotoxicity in neurons by activating the NMDAR; (b) Env (represented as $\Delta$ ) also plays both a direct and indirect role in neurodegeneration. The Env protein gp120 has been shown to interact with both CCR5 and CXCR4 expressed on the surface of neurons and glial cells and subsequently induce neuronal apoptosis. Macrophages and microglia activated by gp120 secrete various proinflammatory factors including cytokines, chemokines and arachidonic acid, resulting in neuronal damage; (c) Vpr (represented as. grey $\bullet$ ) has been shown to increase viral transcription and production in cells of the monocyte/macrophage lineage. Extracellular $\mathrm{Vpr}$ has also been demonstrated to induce apoptosis in undifferentiated and mature neuronal precursor cells; (d) Nef (represented as grey $\boldsymbol{\square}$ ) within the brain has been shown to be predominantly in astrocytes. Stable expression of Nef may alter the growth properties of astrocytes. Nef also demonstrates direct neurotoxicity. When cells of the monocyte-macrophage lineage are exposed to Nef, proinflammatory mediators are released 
Caspase- 3 activation by gp120 has been demonstrated in rat cerebellar granule cells ${ }^{[76]}$, human embryonic kidney cells ${ }^{[77]}$ and human endothelial cells ${ }^{[78]}$. Conversely, studies have shown that caspase-3 inhibition protects neurons from apoptosis, suggesting that therapeutic candidates aimed at inhibiting caspase3 activation may prove valuable in preventing gp120induced neurotoxicity ${ }^{[79]}$.

Calcium homeostasis is disrupted in neurons by gp120-induced perturbation of calcium-regulating systems in the plasma membrane and Endoplasmic Reticulum $(\mathrm{ER})^{[80,81]}$. In addition, gp120 activation of tissue macrophages and microglia initiates glutamaterelated hyperactivation of the N-Methyl-D-Aspartic Acid Receptor (NMDAR), which has been shown to be involved in ER stress and $\mathrm{Ca}^{2+}$ release ${ }^{[82,83]}$. ER stress may be involved early in the process of cellular apoptosis $^{[84]}$ and it is associated with multiple neurodegenerative diseases ${ }^{[85]}$.

Macrophages and microglia activated by gp120 secrete various factors including $\mathrm{TNF}-\alpha$, arachidonic acids and various $\beta$-chemokines, resulting in neuronal damage $^{[6]}$ (Fig. 1). Exposure of astrocytes to gp120 inhibits their ability to take up glutamate, leading to increased glutamate concentrations within the neuronal microenvironment, which results in excitotoxicity ${ }^{[86]}$ (Fig. 1). Additionally, gp120 has been demonstrated to alter gene expression patterns in astrocytes ${ }^{[87,88]}$ and neurons ${ }^{[65]}$, providing evidence that alterations in cellular processes may contribute to neuronal damage.

The HIV-1 transmembrane protein gp41, a protein which links gp120 to the viral envelope has been observed at elevated levels in patients with HAD. Studies have demonstrated gp41 to be lethal to neurons at very low concentrations in the presence of glia and it has been shown that astrocytes exposed to the carboxyterminus of gp41 exhibit defects in glutamate transport and release ${ }^{[89]}$ (Fig. 1). The mechanisms of neurotoxicity induced by gp41 involves activation of iNOS, NO formation, glutathione depletion and interruption of mitochondrial function ${ }^{[90-92]}$.

The HIV-1 accessory protein Vpr: Viral protein R (Vpr) is one of six auxillary proteins encoded for by HIV-1 and several studies have suggested that this protein may have a role in HIV-1-associated neuropathogenesis ${ }^{[13,93-95]}$. HIV-1 $\mathrm{Vpr}$ is a critical accessory protein of 96 amino acids (14 kDa) synthesized from a singly spliced viral mRNA, which may oligomerize ${ }^{[95,96]}$. HIV-1 infection of non-dividing cells such as monoctyes and macrophages is critically dependent on $\mathrm{Vpr}^{[97,98]}$ and the addition of extracellular $\mathrm{Vpr}$ to latently infected $\mathrm{T}$ lymphocytes has been shown to dramatically increase viral replication ${ }^{[99]}$. Vpr has been shown to increase viral transcription and production in cells of the monocyte-macrophage lineage and it may be involved in the translocation of the viral Preintegration Complex (PIC) from the cytoplasm to the nucleus ${ }^{[96,98,100,101]}$. It has been demonstrated that HIV-1 Vpr arrests T lymphocytes in the G2 phase of the cell cycle ${ }^{[97,102-108]}$ and induces adherent cell differentiation ${ }^{[109]}$. Interestingly, $\mathrm{Vpr}$ has also been shown to suppress the immune response in humans by inhibiting clonal expansion of $\mathrm{T}$ cells ${ }^{[110]}$, providing an ideal physiological environment for efficient viral replication ${ }^{[103,111]}$.

$\mathrm{Vpr}$, by binding to the p6 portion of the Gag polyprotein, is incorporated into HIV-1 virons in significant quantities $^{[112]}$ and both purified $\mathrm{Vpr}$, isolated from HIV1-infected patients and recombinant $\mathrm{Vpr}$ has been shown to activate viral replication from latently infected cells. HIV-1 Vpr is primarily localized in the nucleus of the infected cells ${ }^{[113]}$, likely due to the strength of its two nuclear localization signals ${ }^{[14]}$. This nucleophilic property of $\mathrm{Vpr}$ in combination with its presence in the PIC has led to the suggestion that $\mathrm{Vpr}$ may facilitate increased viral replication in nondividing cells like cells of the monocyte-macrophage lineage ${ }^{[98,100,101,115]}$. Some in vitro studies have provided evidence in support of a direct role for $\mathrm{Vpr}$ in PIC import $^{[116,117]}$. However other studies have placed this observation in question ${ }^{[18]}$ and have suggested that $\mathrm{Vpr}$ is not required for HIV-1 infection of non-dividing $\mathrm{T}$ lymphocytes ${ }^{[119]}$.

The mechanism by which $\mathrm{Vpr}$ is incorporated into budding virions, which are assembled in the cytoplasm near the plasma membrane, is not well understood; however, studies have shown that the nuclear export property of $\mathrm{Vpr}$ is required for its efficient incorporation into virions, which is critically important for productive viral replication in tissue macrophages ${ }^{[120]}$. The absence of $\mathrm{Vpr}$ does not prevent HIV-1 infection of tissue macrophages, however, its presence has been demonstrated to greatly enhance infection of these cells ${ }^{[120]}$. Studies have suggested that $\mathrm{Vpr}$ may function like an importin- $\beta$ homologue by directly binding to nucleoporins within the Nuclear Pore Complex (NPC) ${ }^{[16,121,122]}$. Matrix (MA) and Integrase (IN) proteins are known to utilize the importin- $\alpha / \beta$ dependent pathway for nuclear import, however, $\mathrm{Vpr}$ contains a noncanonical NLS and therefore does not use these classical pathways exclusively for nuclear import $^{[101,114,123,124]}$. It may be that HIV-1 has evolved a novel strategy for avoiding cellular defense mechanisms aimed at preventing viruses from entering the nucleus of infected cells. Considering the large and significant role 
that HIV-1-infected macrophages play both in peripheral blood and CNS disease as well as HIV disease in other organ systems, it is reasonable to suggest that interrupting $\mathrm{Vpr}$ function in vivo may lead to a marked decrease in viral burden within HIV-1infected patients and ameliorate some of the deleterious effects of HIV-1 infection.

Mutational studies have revealed that the region of the Vpr responsible for cell-cycle arrest is located in the carboxy-terminal basic domain, while the virion incorporation and nuclear translocation functions of $\mathrm{Vpr}$ are elicited by the $\alpha$-helical amino-terminus, suggesting that Vpr likely effects cellular functions in multiple ways ${ }^{[125-129]}$. Additionally, investigations have shown that $\mathrm{Vpr}$ appears to induce apoptosis in $\mathrm{T}$ lymphocytes $^{[130,131]}$ and studies have revealed that extracellular Vpr induces apoptosis in undifferentiated as well as mature, differentiated NT2 CNS neuronal precursor cells (derived from a human teratocarcinoma cell line $)^{[95]}$. Importantly, $\mathrm{Vpr}$ has also been shown to both activate and differentiate monocytic cells in the bone marrow ${ }^{[132]}$, a cellular compartment believed to be critically important in the neuropathogenesis of the HIV-1. Due to the multiple effects of HIV-1 Vpr on both $\mathrm{T}$ cells and cells of the monocyte-macrophage lineage, in addition to the potential apoptotic effect of extracellular Vpr on neurons, it has been suggested the Vpr very likely plays an important role in CNS damage during the course of HIV-1 infection ${ }^{[13]}$ (Fig. 1).

The HIV-1 auxillary protein Nef: HIV-1 Nef is a nonstructural protein and one of its best known properties is its ability to impact the trafficking of proteins expressed on the surface of cells. Nef has been shown to down-regulate CD4 expression in addition to downregulating expression of a subset of MHC class molecules $^{[133-135]}$, mature MHC class II molecules, CD8, CD28, CCR5, CXCR4 and the transferring receptor ${ }^{[136-}$ ${ }^{142]}$. The downregulation of CD4 in HIV-1-infected cells has been shown to facilitate Env incorporation into infectious virions by inhibiting CD4/gp120 complex formation on the surface of the cells ${ }^{[143-145]}$.

Much like Vpr, Nef is also incorporated into HIV-1 virions $^{[146-149]}$. Nef has been suggested to play a major role in HIV-1 disease progression toward AIDS ${ }^{[150-156]}$ and this increase in viral infectivity associated with Nef may explain the increased pathogenicity of wild-type (wt) HIV-1 compared to $\Delta$ Nef HIV-1 variants ${ }^{[134,157,158]}$. Studies have suggested that Nef may play a role in the fusion of HIV-1 to target cells ${ }^{[159]}$ and that Nef may be involved in certain post-fusion events such as facilitating the trafficking of viral core particles through the cortical actin network ${ }^{[160]}$.
Nef affects cellular function in various ways and Nef has been detected in the supernatants of HIV-1infected cell cultures as well as in sera of AIDS patients $^{[161]}$. Within the brain of HIV-1-infected patients, Nef is found predominately in astrocytes ${ }^{[162]}$. Direct neurotoxicity of Nef has been shown by exposure of neuronal cell cultures to recombinant Nef $(\mathrm{rNef})^{[163]}$ (Fig. 1) and studies have revealed that Nef increases total $\mathrm{K}^{+}$current of chick dorsal root ganglions similar to scorpion neurotoxin ${ }^{[164,165]}$, suggesting that Nef is able to alter the electrophysiological properties of neurons. Exposure of human monocytic cells to extracellular Nef results in the release of inflammatory mediators (Fig. 1) and exposure of neuronal and astrocytic cell lines to rNef leads to the upregulation of complement factor $\mathrm{C} 3^{[166]}$. In addition, studies have indicated that stable expression of Nef may alter growth properties of human astrocytes ${ }^{[162]}$.

HIV-1 transactivator protein Tat: HIV-1 Tat is a viral nonstructural protein of 86-101 amino acids in length and it is the product of two exons ${ }^{[3]}$. Tat, a transactivating nuclear regulatory protein, is critical for viral replication and is secreted by HIV-1-infected cells. Secreted Tat may be taken up by neighboring cells and by this mechanism, Tat is able to elicit affects on both infected and uninfected cells ${ }^{[167,168]}$. Tat has been found in the brains of HIV-1-infected individuals with known CNS pathology ${ }^{[169]}$ and Tat is known to trigger oxidative stress-dependent apoptosis of neurons both in vitro and in vivo.

Previous investigations have shown that HIV-1 subtype B-derived Tat can cause excitotoxcity in neurons by activating $\mathrm{NMDAR}^{[170]}$, however there is some controversy as to whether Tat is able to bind NMDAR directly. Studies have suggested that Tat neurotoxicity is dependent on binding to low-density receptor (LPR) with subsequent activation of $\mathrm{NMDAR}^{[171]}$. A more recent study aimed at comparing the neurotoxic potential of subtype $\mathrm{B}$ and $\mathrm{C}$ Tat protein has suggested that Tat may be able to directly bind to NMDAR ${ }^{[172]}$. More specifically, this study demonstrated that both subtype $\mathrm{B}$ and $\mathrm{C}$ Tat bind directly to NMDAR, however, subtype $\mathrm{C}$ Tat was significantly less neurotoxic. Further analysis of sequence differences between the two Tat subtypes revealed that the attenuated neurotoxicity was due to a Cys31Ser mutation found in subtype $\mathrm{C}$ Tat. Furthermore, engineering this mutation into a subtype B Tat resulted in decreased neurotoxicity similar to that observed with subtype $\mathrm{C}$ Tat. Interestingly, the Cys31Ser mutation had no observable effect on the ability of Tat to bind NMDAR ${ }^{[172]}$, suggesting that other 
regions of the Tat protein are likely responsible for binding, while the Cys residue is involved in NMDAR activation $^{[172]}$. These studies underscore potential importance of differences in HIV-1 subtypes from varying geographical regions and are consistent with the observation that geographical regions infected with subtype B report more severe forms of HIV-1associated neurocognitive impairment as opposed to areas of the world infected with subtype C.

Several studies have shown that NMDAR function may be modulated by dopamine D1-like receptors, composed of D1- and D5-like receptors ${ }^{[173-178]}$ and a recent study has implicated D1-mediated pathways in the mechanism of Tat-induced neurotoxicity ${ }^{[3]}$. HIV-1 Tat may influence the activity of D1 receptors in postsynaptic neurons, thereby resulting in NMDARregulated apoptotic cascades via D1/NMDAR interaction, or alternatively, NMDAR activation in D1expressing neurons exposed to Tat may up regulate proapoptotic D1-mediated signaling ${ }^{[3]}$.

Tat has been detected in the brains of patients with HIV-1 encephalitis (HIVE) by both mRNA and immunoblot analysis, however the source of the Tat detected in these circumstances is unclear ${ }^{[179]}$. The Tat observed in the brains of these patients may be secreted by infected cells within the CNS, or it may be specifically transported across the BBB from the periphery ${ }^{[180]}$. Either way, once in the brain, Tat may be taken-up by resident cells of the CNS, often resulting in toxic consequences including neuronal apoptosis ${ }^{[181-183]}$ (Fig. 1). Importantly, studies have shown that Tat can be transported along anatomical pathways within the CNS, indicating that sites of neuronal injury and the site of actual viral infection may be distinct from one another ${ }^{[184]}$.

The uptake of Tat by uninfected cells results in deleterious events in both the cytoplasm and nucleus, including altered gene transcription, cytokine secretion, NMDAR activation in neurons and the initiation of apoptotic cascades ${ }^{[3,46,167,168]}$. A combination of these cellular events are likely involved in neuronal apoptosis in response to HIV-1 infection and the secretion of Tat, however the exact mechanism is not well understood. It is generally accepted that glutamate and glutamate receptors are involved in the process of neuronal cell death, which suggests that HIV-1-associated neurologic disease pathogenesis may involve mechanisms similar to those of other neurodegenerative disease processes with respect to glutamate dysregulation and excitotoxicity ${ }^{[3]}$.

HIV-1 Tat is known to interact with various receptors expressed on different cell types including integrins, VEGF receptor (KDR/flk) and possibly
CXCR $4^{[185,186]}$. With respect to neurons, Tat uptake and internalization occurs primarily via the Lipoprotein Related Protein (LRP) receptor, which is expressed on the cell surface ${ }^{[187]}$. There are at least 16 ligands for LRP and in the brain it is expressed on both neurons and activated astrocytes ${ }^{[185]}$. Tat is the only known ligand of LRP that induces significant levels of apoptosis, the reasons for which are not known. Following ligand binding to LRP, the receptor-ligand complex is internalized. However, in the case of Tat, when it binds to LRP it escapes from endosomes to the cytoplasm and it can be found localized in both the cytoplasm and nucleus where it may affect cellular signaling pathways ${ }^{[188]}$.

Exposure of astrocytes to Tat, either extracellularly through viral infection or intracellularly via transient transfection, results in the induction of cellular inflammatory mediators (Fig. 1). Treatment of human fetal astrocytes with extracellular Tat has been shown in induce production of CCL2 (monoctye chemoattractant protein-1, MCP-1 $)^{[189]}$. CCL2 is involved in the recruitment of monocytes to sites of inflammation in the CNS and it induces monocytic cells to cross the BBB and traffic to the site of secretion. Furthermore, it has been demonstrated that individuals with HIVE have elevated levels of CCL2 in their CSF and even higher levels have been associated with $\operatorname{HAD}^{[189,190]}$. Interestingly, human astrocytes take up Tat and become activated to produce chemokines as well as Nitric Oxide (NO), however, these cells do not undergo apoptosis unless they are co-cultured with neurons ${ }^{[168,181,191]}$. It has been suggested that Tatinduced apoptosis of astrocytes requires a yet to be identified signal from NMDAR-positive neurons ${ }^{[171]}$.

Monocytes recruited to the CNS by CCL2 secrete cytokines and neurotoxic mediators ${ }^{[6]}$. A primary function of astrocytes is to regulate extracellular glutamate levels in the brain and it has been demonstrated that monocyte-secreted TNF- $\alpha$ impedes glutamate metabolism by human astrocytes, resulting in altered glutamate homeostasis, accumulation of extracellular glutamate and potentially neuronal injury ${ }^{[192]}$. In addition to the effect of Tat on glutamate metabolism in astrocytes and the resulting neuronal glutamate excitotoxicity, other mechanisms are known by which astrocytes contribute to neuronal toxicity and apoptosis. Tat-treated astrocytes express inducible Nitric Oxide Synthase (iNOS) via activation of the NF$\kappa \mathrm{B}$ and $\mathrm{C} / \mathrm{EBP} \beta$ pathways and the ERK/MAPK pathway contributes to NO production in astrocytes by activation of $\mathrm{C} / \mathrm{EBP} \beta^{[191]}$. The NO produced by this mechanism may initiate apoptotic events in neighboring neurons. 
Microglia are resident macrophages in the CNS and the most predominate cell type to be productively infected by HIV-1 in the brain ${ }^{[171]}$. Despite the relatively high level of HIV-1 infection of resident microglia, neurocognitive impairment does not correlate with viral load in the brain, but rather with neuroinflammation ${ }^{[193]}$. Activated microglial cells secrete pro-inflammatory factors including cytokines and chemokines, reactive oxygen species, reactive nitrogen species and excitatory amino acids, which leads to the recruitment of additional inflammatory cells to the brain. Due to the fact that some of the inflammatory mediators secreted by microglia are known to be neurotoxic, like quinolinic and arachidonic $\operatorname{acids}^{[194]}$, it has been suggested that activation of microglia may contribute both directly and indirectly to neuronal damage and apoptosis within the context of the HIV-1 infection of the CNS ${ }^{[171]}$ (Fig. 1).

Overview of HTLV-1 neuropathogenesis: The debilitating neuroinflammatory disease, HAM/TSP, is characterized by over-stimulation of the immunologic compartment, including increased expression of a repertoire of inflammatory cytokines and chemokines, HTLV-1 transactivator protein Tax- and gp46-specific antibodies directed against a number of cellular determinants (including the heteronuclear ribonuclear protein $\mathrm{A} 1$, hnRNP A1 ${ }^{[195]}$ and an increase in the number of highly activated circulating $\mathrm{CD}^{+} \mathrm{T}$ cells directed against the $\mathrm{Tax}_{11-19}$ epitope in both Peripheral Blood (PB) and Cerebrospinal Fluid (CSF) ${ }^{[196]}$. In the acute stage of HAM/TSP, both $\mathrm{CD} 4^{+}$and $\mathrm{CD} 8^{+} \mathrm{T}$ cells have been shown to accumulate in lesions of the spinal cord; however, during chronic disease, $\mathrm{CD} 8^{+} \mathrm{T}$ cells are the predominant cellular infiltrate in regions of demyelination ${ }^{[197-199]}$. In some HLA-A*201 HAM/TSP patients, the frequency of $\operatorname{Tax}_{11-19}$-specific CTLs is as high as $20 \%$ of all $\mathrm{CD}^{+} \mathrm{T}$ cells in the PB and even higher in the $\operatorname{CSF}^{[195,196,200-203]}$. During the course of HAM/TSP, various cells of the immune system are infected by HTLV-1 in the PB and tissues. These cells are also likely infected as BM progenitor cells as a result of viral spread from HTLV-1-infected $\mathrm{CD}^{+} / \mathrm{CD} 25^{+} \mathrm{T}$ cells as these cells traffic back into the BM from the blood. Trafficking of HTLV-1-infected T cells back into the BM over long periods of time has led to the development of a large population of HTLV-1 proviral $\mathrm{DNA}^{+} / \mathrm{RNA}^{-}$latently infected cells in the $\mathrm{BM}$ of HAM/TSP patients ${ }^{[204]}$. Additional studies involving HTLV-1-infected CD34 ${ }^{+}$human BM progenitor cells transplanted into immunocompromised mice led to the development of equivalent numbers of proviral $\mathrm{DNA}^{+}$ cells within defined immune cell lineages, suggesting that maintenance of the proviral genome does not have any detectable impact on lineage development ${ }^{[205]}$. In addition to the route of exposure (mucosal versus blood-borne) and the inherent differences in the associated primary immune response, the following factors likely play important roles in the genesis and progression of cancer and/or neurologic disease caused by HTLV-1: (i) Viral genomic architecture, (ii) Genetic background of the human host, (iii) HTLV-1 proviral DNA load, (iv) Relative levels of HTLV-1-specific RNA-positive $\mathrm{CD}^{+} / \mathrm{CD} 25^{+} \mathrm{T}$ cells, (v) Concentrations of secreted extracellular viral proteins such as Tax, (vi) The impact of extracellular viral proteins on cells of immune and nervous system origin, (vii) Relative levels of HTLV-1-specific antibodies that exhibit crossreactivity to cellular proteins, (viii) Relative levels of HTLV-1-specific $\mathrm{CD}^{+} \mathrm{T}$ lymphocytes and (ix) Relative levels of HTLV-1-susceptible primary and secondary target cells in the immune and nervous system $^{[200,201,206-210]}$. Figure 2 depicts these scenarios in the context of molecular pathogenesis of HAM/TSP.

Nuclear localization and Tax-mediated regulation of cellular genes and viral promoter: The HTLV-1 oncoprotein Tax has been studied extensively with respect to its role in regulating cellular and viral gene expression during the course of HTLV-1 infection of human CD4+ T ells (primary target ell opulation) ${ }^{[211-213]}$. In particular, these studies have focused on the molecular mechanisms pertaining to the interaction of Tax with nuclear proteins during transcriptional transactivation of cellular and viral gene expression prior to and/or subsequent to Tax localization to the nucleus. One of the major roles of Tax in productive viral replication involves the interaction with host transcriptional machinery to facilitate the binding of cellular transcription factors to the HTLV-1 LTR. Viral gene expression occurs by the binding of Tax to the three 21-bp Tax responsive elements collectively referred to a Tax Responsive Element 1 (TRE-1) that are located within the U3 region of the $\mathrm{LTR}^{[214-216]}$. Each of the three 21-bp repeat elements is comprised of three domains A, B and C. Among these, the central domain $\mathrm{B}$ has been shown to closely mimic a cyclic AMP (cAMP) responsive element (CRE) with a conserved 8 -nucleotide (nt) core sequence (TGACGTCA) that is flanked by $5^{\prime}$ and $3^{\prime}, \mathrm{G} / \mathrm{C}$ rich sequences ${ }^{[217]}$. The recruitment of the cellular transcription factors-CRE Binding protein (CREB) and serum response factor (SRF or p67 ${ }^{\mathrm{SRF}}$ )-to the CRE by Tax, facilitates transcription ${ }^{[218,219]}$. The interaction of Tax with dimeric CREB as a homodimer, results in the formation of a ternary complex that in turn helps to stabilize the CREB/21-bp repeat complex formation ${ }^{[217,220]}$. 


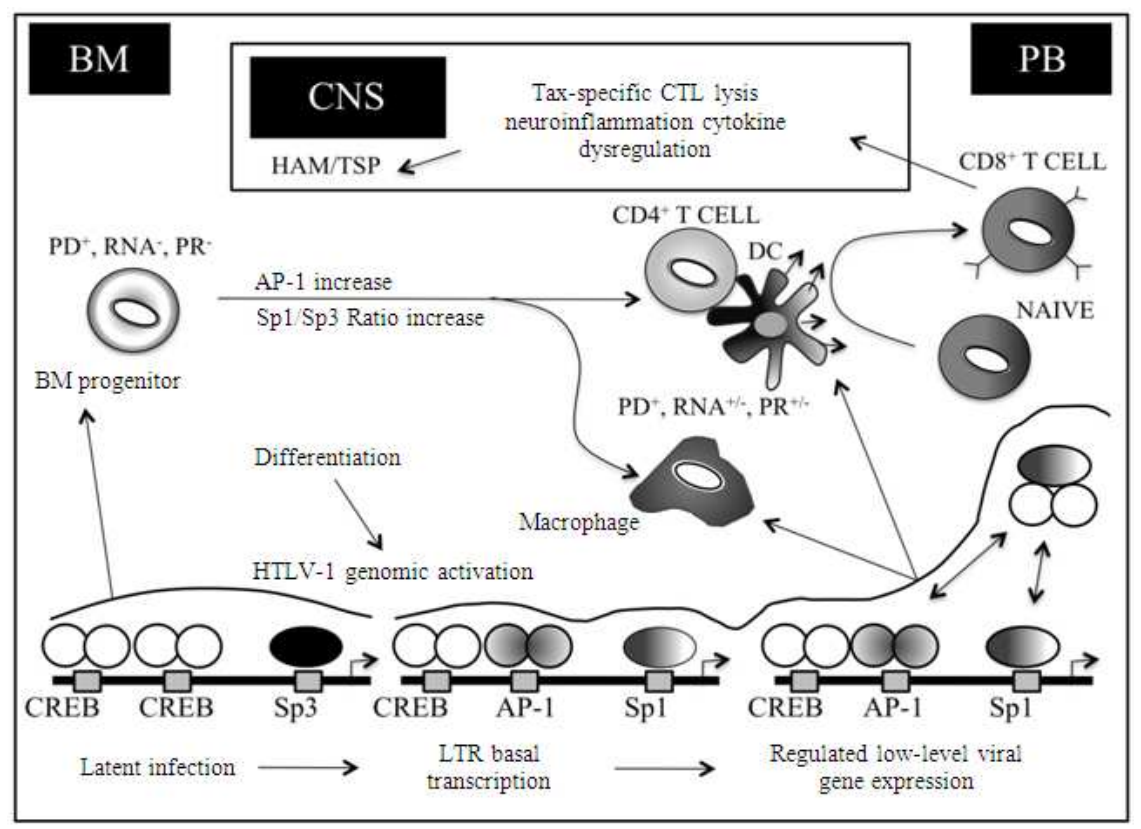

Fig. 2: Overview of the HTLV-1 LTR regulation as it relates to HAM/TSP pathogenesis. The progressive stages of $\mathrm{HAM}$ /TSP are characterized by the presence of activated $\mathrm{CD} 4^{+}$and $\mathrm{CD} 8^{+} \mathrm{T}$ cells and macrophages in demyelinating lesions. At these sites an array of proinflammatory cytokines are produced facilitating further recruitment of inflammatory cells into the CNS. CD4 ${ }^{+} \mathrm{T}$ cells represent the chief source of viral gene expression and along with the help of antigen presenting cells such as dendritic cells activate $\mathrm{CD} 8^{+} \mathrm{T}$ cells. HTLV-1-specific $\mathrm{CD}^{+} \mathrm{T}$ cells traffic to and accumulate within the CNS throughout the course of neurologic disease. Therefore, the presence of activated HTLV-1-specific CD8 ${ }^{+}$CTL and macrophage populations in the CNS may result in the maintenance of a persistent CTL response against infected cells expressing viral antigens and proinflammatory cytokine-mediated bystander damage. During this process, differentiation of infected bone marrow progenitor cells lead to HTLV-1 genomic activation and an increased viral gene expression mediated by Tax-CREB dimer formation and the cell type-specific activity of different transcription factors such as $\mathrm{AP}-1, \mathrm{C} / \mathrm{EBP}$ and $\mathrm{Sp} 1 / \mathrm{Sp} 3$. BM, bone marrow; CNS; central nervous system; PB, peripheral blood; PD, proviral DNA; PR, proviral replication; DC, dendritic cell

As a consequence of the formation of this stabilized complex, the two cellular coactivators-p300/CREBBinding Protein (p300/CBP) and p300/CBP-associated factor $(\mathrm{P} / \mathrm{CAF})$ are then recruited independently by $\mathrm{Tax}$ by binding to the two distinct regions in the amino and carboxy terminus of Tax, respectively. Transcription is then finally initiated by histone acetylation mediated through remodeling of the chromatin structure ${ }^{[221-223]}$. In addition, Tax is also known to activate various cellular signaling pathways such as the NF-KB and ATF/CREB pathways. The NF- $\mathrm{KB}$ is a cytoplasmic transcription factor which when activated by Tax leads to the phosphorylation and degradation of the bound inhibitory proteins (IKBs) thereby allowing the release and eventual translocation of the NF- $\kappa \mathrm{B}$ to the nuclei ${ }^{[224,225]}$. The ATF/CREB family plays an important role in viral transcription as well as Tax- mediated transcription of cellular genes. CREB is activated by phosphorylation in response to the intracellular secondary-messenger cAMP via the cAMP dependent Protein Kinase A (PKA) signaling pathway ${ }^{[226-228]}$. Numerous studies have focused on the interaction between Tax and CREB-1 with TRE-1 and the importance of this interaction in the activation of viral gene transcription mediated by the TRE-1 21-bp repeats ${ }^{[216,229]}$. These studies have demonstrated that direct and indirect interaction of Tax with a spectrum of cellular transcription factors may be involved in the differential regulation of both cellular gene expression and viral LTR activation in T cells and other secondary target cell populations.

Mechanism of HTLV-1 LTR activation in secondary target populations: Clearly, the interaction of HTLV-1 
with the $\mathrm{CD}^{+} / \mathrm{CD} 25^{+} \mathrm{T}$ lymphocyte compartment represents a key encounter that leads to either cell death resulting from programmed viral gene expression and production of progeny virus, or oncogenic transformation based on monoclonal expansion of infected cells. In addition to the $\mathrm{CD} 4^{+} / \mathrm{CD} 25^{+} \mathrm{T}$ cells, other immune cell populations, such as $\mathrm{CD} 34^{+} \mathrm{BM}$ progenitor cells ${ }^{[230,231]}$, cells of the monocytemacrophage lineage ${ }^{[232]}$, antigen presenting cells such as Dendritic Cells (DCs), or cells in the nervous system such as astrocytes and microglial cells ${ }^{[232-236]}$ are also susceptible to productive HTLV-1 infection ${ }^{[237]}$. Viralinduced alterations in these cell compartments likely play important roles in the genesis of HAM/TSP. However, despite the demonstrated susceptibility of these cells very little information exists concerning the molecular mechanisms regulating HTLV-1 LTR activation in these pathogenically relevant secondary target cell populations as compared to $\mathrm{CD}^{+} / \mathrm{CD} 25^{+} \mathrm{T}$ cells. Therefore, we have initiated efforts to define the mechanism of HTLV-1 LTR activation during monocytic differentiation in parallel with our studies on HIV-1 LTR regulation in a similar system ${ }^{[33,38,238]}$. Several members of the CCAAT/Enhancer-Binding Protein (C/EBP) family, including $\mathrm{C} / \mathrm{EBP} \beta$, are expressed at high levels in cells of the monocytemacrophage lineage ${ }^{[239]}$ and are intimately involved in the regulation of myelocytic-monocytic gene expression. Results of these studies have shown that low-level basal activation of the HTLV-1 LTR was significantly enhanced by overexpression of C/EBP $\beta$, $\mathrm{C} / \mathrm{EBP} \delta$, or $\mathrm{C} / \mathrm{EBP} \varepsilon$, whereas transactivation of the HTLV-1 LTR by Tax was inhibited by overexpression of $\mathrm{C} / \mathrm{EBP} \alpha$ and $\mathrm{C} / \mathrm{EBP} \beta$ and to a lesser extent by $\mathrm{C} / \mathrm{EBP} \delta^{[240]}$. In addition, the Activator Protein 1 (AP-1) family of transcription factors was also shown to modulate HTLV-1 LTR activation during phorbol esterinduced differentiation of monocytes ${ }^{[241]}$. The binding sites for the Stimulating protein (Sp) family of transcription factors ( $\mathrm{Sp} 1$ and $\mathrm{Sp} 3$ ) have been identified within the U3 region of the HTLV-1 LTR ${ }^{[242]}$. Recent results have suggested that both $\mathrm{Sp} 1$ and $\mathrm{Sp} 3$ binding to HTLV-1 TRE-1 promoter proximal repeat III within the viral LTR participate in regulation of the LTR by Tax. However, a majority of studies related to HTLV-1 LTR activation $^{[221,243-245]}$ have been performed with transiently transfected LTR plasmids as opposed to chromosomally integrated LTRs that represent an obligatory step in the HTLV-1 life cycle. A report by Okada and Jeang indicated differential requirements for activation of integrated and transiently transfected HTLV-1 LTRs in HeLa and CHOK1 cells by CREB, p300 and P/CAF transcription factors ${ }^{[246]}$. Our recent studies also revealed critical differences in the regulation of transiently transfected and chromosomally integrated HTLV-1 LTR in $\mathrm{T}$ cells (Rahman, Wigdahl and Jain, unpublished observations). Therefore, understanding how the HTLV1 LTR is regulated when formatted in the context of chromatin is important for elucidating the biology of the provirus within cell populations representative of those encountered during the course of disease.

Tax nuclear export, cytoplasmic trafficking and cellular secretion: Tax is localized in both the nucleus and cytoplasm within cells (reviewed in $^{[247]}$ ). The nuclear accumulation of Tax is promoted by an NLS found within the first 58 amino acids of the aminoterminus of the protein, a signal that is unique when compared to classical NLSs ${ }^{[248,249]}$ in that the signal is suspected to involve some form of conformational element. In addition to being an intracellular/nuclear protein, Tax has been shown to be present in the serum and CSF of HAM/TSP patients ${ }^{[250]}$. However, it is unclear whether the cell-free Tax was the result of apoptosis or necrosis of HTLV-1-infected cells or if it was secreted from the infected cell populations. Consistent with the concept of cellular secretion, we have reported the presence of a leucine rich NES between amino acids 188-200 of Tax. We have also reported that the Tax NES may function as a masked NES and may be hidden by a protein-protein interaction, allowing the Tax NLS to remain the predominant localization signal and directing protein localization to the nucleus. Furthermore, Tax tertiary structure may be altered during the successive steps in which the NES is subsequently exposed to cellular export machinery. Alternatively, Tax nuclear export may be regulated through a secondary protein modification such as phosphorylation or acetylation. In this regard, Tax phosphorylation has been studied in various cell types and alterations in the pattern of Tax accumulation within the cytoplasm have been reported $^{[251,252]}$. The release of Tax in the extracellular environment has also been reported from HTLV-1infected cells ${ }^{[253]}$. We have also demonstrated the secretion of full-length Tax in the cell culture media of Tax-transfected cells where Tax secretion was, at least in part, dependent on a formal cellular secretory pathway ${ }^{[254]}$. Proteins destined for the cell surface or those released into the extracellular environment proceed through the cellular secretory pathway after being synthesized and inserted into the Endoplasmic Reticulum (ER) ${ }^{[255]}$. We have previously demonstrated that Tax co-localizes with cytoplasmic organelles relevant to secretion such as ER and golgi complex and the movement of Tax within the cytoplasm was found 
to be characteristic of secretory vesicles ${ }^{[254]}$. Evidence was also presented demonstrating that microtubules and the conventional motor protein kinesin are likely involved in shuttling Tax-containing secretory vesicles from the Golgi to the plasma membrane ${ }^{[254]}$. Subsequent to proper folding in the ER, secretory proteins are then sorted from resident ER proteins and concentrated into ER exit sites that form coat protein complex II (COPII)-coated vesicles. COPII vesicles mediate transport of proteins from the ER to the cis$\mathrm{Golgi}^{[256]}$. Concentration of proteins into COPII vesicles within the ER occurs through a cargo selection motif found on most secreted proteins. This motif has been shown to consist of a di-acidic signal comprised of an aspartic or glutamic acid bordering a variable residue (D/ExE/D) also known as a DXE signal ${ }^{[257-259]}$. Table 1 shows the known amino acid signals implicated in targeting proteins to the cellular secretory pathway. While this signal only partially accounts for efficient exit from the ER, mutation of this signal has been demonstrated to reduce accumulation of protein in COPII vesicles ${ }^{[260]}$. Analysis of the Tax amino acid sequence has revealed the presence of a number of putative secretory signals within the carboxy-terminal domain, of which two putative secretory signals, DHE and a four amino acid di-hydrophobic tyrosine-based motif (YTNI), were found to be essential for Tax secretion ${ }^{[261]}$. Additionally, Tax was shown to interact with a number of proteins (Fig. 3) involved in the cellular secretory pathway ${ }^{[261,262]}$ suggesting that release of Tax into the extracellular environment is a regulated event that is facilitated by the interaction of Tax with cellular secretory pathway proteins and the presence of

Table 1: Amino acid signals implicated in targeting proteins to the cellular secretory pathway

\begin{tabular}{|c|c|c|}
\hline \multirow{2}{*}{$\begin{array}{l}\text { Sorted protein } \\
\text { Di-acidic: }\end{array}$} & \multicolumn{2}{|c|}{ Single sequence Role of signal sequence } \\
\hline & & \\
\hline VSV-g (virus) & DXE & $\begin{array}{l}\text { Cargo concentration and } \\
\text { exit from ER }\end{array}$ \\
\hline Syspl (yeast) & DXE & $\begin{array}{l}\text { Binding to } 23 \mathrm{sec} / 24 \mathrm{sec} \text { of } \\
\text { COPII coat }\end{array}$ \\
\hline Kir 1.1 (mammalian) & DXE & ER export \\
\hline Kir 2.1 (mammalian) & DXE & ER export \\
\hline \multicolumn{3}{|c|}{ Di-hydrophobic tyrosine-based } \\
\hline SIV env (viral) & YRPV & ? \\
\hline HIV gp 160 (viral) & YSPL & ? \\
\hline TGN38 (mammalian) & YQRL & Targets protein to the TGN \\
\hline Emp46p (yeast) & YYMF & $\begin{array}{l}\text { ER export/localization to } \\
\text { Golgi }\end{array}$ \\
\hline \multicolumn{3}{|c|}{ D-hydrophobic tyrosine-based: } \\
\hline ERGIC-53 (mammalian) & FF & ER export \\
\hline Sysp 1(yeast) & FF & Non-functional \\
\hline P24 family (mammalian) & FF & $\begin{array}{l}\text { Binding to } 23 \mathrm{sec} \text { COPII } \\
\text { component in vitro }\end{array}$ \\
\hline \multicolumn{3}{|l|}{ D-hydrophobic Di-leucine: } \\
\hline Emp24 (yeast) & LV & $\begin{array}{l}\text { ER export/incorporation } \\
\text { into COPII vesicles }\end{array}$ \\
\hline Vam3p (yeast) & LL & Sorting to golgi \\
\hline Erv41p-Erv46p (yeast) & IL & Packing into COPII vesicles \\
\hline
\end{tabular}

critical secretory signals within the carboxy-terminal domain of Tax. Once released, Tax could work as an extracellular effectors molecule, the minute quantity of which may cause major pathogenic changes.

Role of extracellular tax in HTLV-1 neuropathogenesis: Extracellular Tax has been shown to induce the production of TNF- $\alpha$ from a human neuronal cell line at a concentration that has been shown to be produced by HTLV-1-infected cells ${ }^{[263,264]}$. Release of TNF- $\alpha$ may result in both an autocrine and paracrine cytokine-mediated destruction of neuronal tissue. Other pathologic processes observed in HAM/TSP patients include demyelination of CNS neurons, which may also be a direct effect of extracellular Tax ${ }^{[263,265]}$. In addition to neurons, adult human microglial cells were also shown to secrete TNF- $\alpha$, IL- $1 \beta$ and IL- 6 in response to $\mathrm{Tax}^{[266]}$. These observations correlate with additional studies demonstrating that HTLV-1infected microglial cells secrete both TNF- $\alpha$ and IL-6 but not IL-1 $\beta$, suggesting that Tax may have a paracrine effect on other Tax-producing cells ${ }^{[266]}$.

\begin{tabular}{|c|c|c|}
\hline $\begin{array}{c}\text { Nucleoplasmic } \\
\text { shuttling }\end{array}$ & ER/golgi transport & Post-golgi transport \\
\hline \multirow{3}{*}{ Nucleopotins } & & SNARE \\
\hline & Coat proteins & t-SNAREs \\
\hline & COPII & v-SNAREs \\
\hline Importins & $\beta \mathrm{COP}(\mathrm{COPI})$ & SNAP2 \\
\hline NTF p97 & AA signals & SCAMPs \\
\hline Exportins & DXE & \\
\hline CRM1 & $\mathrm{YXX}_{\phi}$ & Tubulin (MTs) \\
\hline Calreticulin & $\mathrm{LL} / \mathrm{LV}$ & Kinesin \\
\hline
\end{tabular}

Fig. 3: Components of the cellular secretory pathway important for nucleocytoplsmic shuttling, endoplasmic reticulum to golgi transport and post-golgi transport to the plasma membrane. While NTF p97 may facilitate nuclear import of Tax, CRM1 and calreticulin may facilitate its export through the nuclear pore complex. Tax is likely targeted to the secretory pathway by being transported into the Endoplasmic Reticulum (ER). Once in the ER, Tax likely moves to the Golgi by inclusion into COPII vesicles. Amino acid signals within Tax including ${ }^{330}{ }^{3 H E^{332}}$ and ${ }^{312}$ YTNI $^{315}$ were shown to be important for targeting Tax to the Golgi. A portion of Tax may also be returned to the ER via retrograde transport by inclusion into COPI vesicles. In the Golgi, Tax is likely included into secretory vesicles through its interaction with SCAMPs and vSNAREs including SNAP23 
The effects of extracellular Tax have not been limited to the CNS, primary human $\mathrm{PB}$ macrophages have also been shown to secrete TNF- $\alpha$, IL-1 and IL-6 in response to extracellular $\mathrm{Tax}^{[266]}$. Recently, cell-free Tax has been demonstrated in the CSF of HAM/TSP patients ${ }^{[250]}$ indicating that Tax is available for immune recognition by APCs. Extracellular Tax released from Tax-producing cells by secretion or apoptosis and necrosis may be internalized by professional APCs. Tax peptides presented in the context of MHC by APCs would result in lysis of Tax-expressing cells by Taxspecific $\mathrm{CD}^{+} \mathrm{T}$ cells. Either production of toxic molecules or specific cell lysis could result in significant CNS damage similar to that observed in HAM/TSP. DCs are the most potent APCs and are of particular significance in the context of HTLV-1 pathogenesis. Development of HAM/TSP is associated with rapid maturation of $\mathrm{DCs}^{[267]}$, while ATL is associated with a defect in their maturation ${ }^{[268]}$. DCs obtained from the PB of HAM/TSP patients were found to be infected with HTLV-1 ${ }^{[269]}$. Similarly, DCs can be infected with HTLV-1 in vitro and when subsequently matured, can stimulate autologous $\mathrm{CD} 4^{+}$and $\mathrm{CD} 8^{+} \mathrm{T}$ cells ${ }^{[270]}$. Therefore, we hypothesized that DCs and other APCs might play a critical in the induction of Tax-specific immune response during the progression of HAM/TSP. In initial studies, the effects of intracellular versus extracellular and retrovirallyintroduced Tax on murine DCs ${ }^{[271]}$ have been analyzed. We have also studied activation and maturation of primary human monocyte-derived DCs as well as myeloid DCs in response to purified Tax and observed that Tax induces the secretion of proinflammatory cytokines and $\beta$ chemokines from $\mathrm{DCs}^{[272,273]}$ and modulates DC function toward a Th1 type immune response $^{[274]}$. Moreover, DC-mediated priming of Taxspecific CTL response was demonstrated both in vitro and in vivo (Manuel and Jain, unpublished observations). These studies strongly suggest that DCs represent a major factor in HAM/TSP pathogenesis. The well-defined target of Tax activity, NF- $\mathrm{KB}$ coupled with protein kinases and phospholipase $\mathrm{C}$, was also found to be critical for Tax-mediated DC activation and maturation $^{[274]}$. Collectively, these studies have provided important insight into the molecular and immunologic mechanisms underlying the development of neuroinflammatory syndromes associated with HTLV-1 and other retroviruses. However, several outstanding questions still remain unanswered relative to the restricted epidemiological distribution of HAM/TSP, viral control mechanisms in asymptomatic carriers, progression to HAM/TSP and possible therapeutic interventions.

\section{CONCLUSION}

HIV-1 CNS disease is largely dependent on the trafficking of infected monocytic cells from the periphery across the blood-brain barrier, where virus is subsequently disseminated to susceptible cell populations within the brain including microglia, perivascular macrophages and astrocytes, which produce neurotoxic viral proteins such as Tat, gp120, Nef and Vpr and cytokines and chemokines that induce a positive feedback mechanism for further recruitment during the course of pathogenesis. HTLV-1 during neuroinflammatory disease is also characterized by an over-stimulation of the immunologic compartment, however instead of monocytes and macrophages it is $\mathrm{CD} 8^{+} \mathrm{T}$ cells specific for $\operatorname{Tax}_{11-19}$ along with increased inflammatory cytokines and chemokines. Interestingly, as described above and restated here in both cases, pathogenesis is caused primarily from the inflammatory response to the neurotoxic proteins.

Unfortunately, in the case of both diseases there are very few treatment options for patients with retrovirusinduced neurologic disease. In the case of HIV-1 while antiretroviral therapy has had great impact on the life expectancy of patients and impacted their viral load and peripheral disease, it has increased the prevalence of neurologic disease ${ }^{[4]}$. With the widespread use of Highly Active Antiretroviral Therapy (HAART), a more subtle form of CNS dysfunction, termed Minor Cognitive Motor Disorder (MCMD), has become more common $^{[7,8]}$. In the HAART era, it is estimated that $\sim 10 \%$ of HIV-infected adults develop HAD, however, the appearance of MCMD may be several times more common, involving as many as $30 \%$ of the HIVinfected population ${ }^{[8,275]}$. Furthermore, the clinical presentation of MCMD has been associated with neuropathological changes characteristic of HIV encephalitis (HIVE) and MCMD is associated with a worse overall prognostic outlook ${ }^{[7,8,275]}$. One means of explaining the development of MCMD is that the lowlevel viral replication associated with successful HARRT regimens, may lead to slowly progressing neurodegeneration. This is consistent with the longer lifespans of patients receiving HAART and possibly with the inability of certain antiretroviral drugs to effectively penetrate into the brain ${ }^{[276]}$. In addition to this, what is known about HIV-1 CNS disease is mostly from studying subtype B viruses. HIV-1 Subtype B viruses only cause a fraction of the worlds infection with subtype $\mathrm{C}$ infection being responsible for approximately half of the world's HIV-1 infections. Unfortunately, little is known about subtype $\mathrm{C}$ viruses and there role in neurologic disease and it is here where 
a majority of the future research will need to be performed.

HTLV-1 neurologic disease is also poorly understood with little or no treatment available. Many questions still remain unanswered as to what drives an infected individual to develop ATL versus HAM/TSP. These have been discussed above, however, the viral protein Tax plays a important role in neuropathogenesis. The levels of this protein being secreted and its presentation by dendritic cells to $\mathrm{T}$ cells plays a major role in HAM/TSP. Consequently, this immunologic pathway may provide an opportunity to identify novel therapeutic interventions.

Overall these two human retroviruses share many similarities. Their ability to cause neurologic disease is just one of the many. The fact that they do so in very similar ways is a testament to how these viruses may have evolved within their human hosts. Tat and Tax are just another example of this similarity, in that, both of these viral proteins interact with their viral LTRs and ultimately act as secreted proteins potentially causing dysregulation of a number of cell populations. It is through the study of the similarities and differences between these two viruses that scientists continue to learn more information concerning the pathogenic mechanisms of these two important human pathogens and their role in neurologic disease.

\section{ACKNOWLEDGEMENT}

These studies were funded in part by the Public Health Service, National Institutes of Health through grants (B. Wigdahl, Principal Investigator) from the National Institute of Neurological Disorders and Stroke (NS32092 and NS46263) and the National Institute of Drug Abuse (DA19807).

\section{REFERENCES}

1. Chen, W., Z. Tang, P. Fortina, P. Patel, S. Addya, S. Surrey, E.A. Acheampong, M. Mukhtar and R.J. Pomerantz, 2005. Ethanol potentiates HIV-1 gp120-induced apoptosis in human neurons via both the death receptor and NMDA receptor pathways. Virology, 334: 59-73. http://www.ncbi.nlm.nih.gov/pubmed/15749123

2. McArthur, J.C., 1987. Neurologic manifestations of AIDS. Medicine (Baltimore), 66: 407-437. http://www.be-

md.ncbi.nlm.nih.gov/pubmed/3316921

3. Silvers, J.M., M.V. Aksenova, M.Y. Aksenov, C.F. Mactutus and R.M. Booze, 2007. Neurotoxicity of HIV-1 Tat protein: Involvement of D1 dopamine receptor. Neurotoxicology, 28: 1184-1190. http://www.ncbi.nlm.nih.gov/pubmed/17764744
4. Childs, E.A., R.H. Lyles, O.A. Selnes, B. Chen and E.N. Miller et al., 1999. Plasma viral load and CD4 lymphocytes predict HIV-associated dementia and sensory neuropathy. Neurology, 52: 607-613. http://www.neurology.org/cgi/content/abstract/52/3/607

5. Gendelman, H.E. and Y. Persidsky, 2005. Infections of the nervous system. Lancet Neurol, 4: 12-13. http://linkinghub.elsevier.com/retrieve/pii/S147444 2204009512

6. Kaul, M., G.A. Garden and S.A. Lipton, 2001. Pathways to neuronal injury and apoptosis in HIVassociated dementia. Nature, 410: 988-994. http://www.ncbi.nlm.nih.gov/pubmed/11309629

7. McArthur, J.C., N. Haughey, S. Gartner, K. Conant, C. Pardo, A. Nath and N. Sacktor, 2003. Human immunodeficiency virus-associated dementia: An evolving disease. J. Neurovirol., 9: 205-221. http://www.ncbi.nlm.nih.gov/pubmed/12707851

8. Cherner, M., E. Masliah, R.J. Ellis, T.D. Marcotte, D.J. Moore, I. Grant and R.K. Heaton, 2002. Neurocognitive dysfunction predicts postmortem findings of HIV encephalitis. Neurology, 59: 1563-1567. http://www.ncbi.nlm.nih.gov/pubmed/12451198

9. Alirezaei, M., D.D. Watry, C.F. Flynn, W.B. Kiosses, E. Masliah, B.R. Williams, M. Kaul, S.A. Lipton and H.S. Fox, 2007. Human immunodeficiency virus-1/surface glycoprotein 120 induces apoptosis through RNA-activated protein kinase signaling in neurons. J. Neurosci., 27: 11047-11055. DOI: 10.1523/JNEUROSCI.2733-07.2007

10. Gartner, S., 2000. HIV infection and dementia. Science, 287: 602-604.

11. Power, C., M.J. Gill and R.T. Johnson, 2002. Progress in clinical neurosciences: The neuropathogenesis of HIV infection: host-virus interaction and the impact of therapy. Can. J. Neurol. $\quad$ Sci., 29: 19-32. http://www.ncbi.nlm.nih.gov/pubmed/11858531

12. Kaul, M. and S.A. Lipton, 2004. Signaling pathways to neuronal damage and apoptosis in human immunodeficiency virus type 1-associated dementia: Chemokine receptors, excitotoxicity and beyond. J. Neurovirol., 1: 97-101. http://www.cababstractsplus.org/abstracts/Abstract. aspx?AcNo=20043207292

13. Patel, C.A., M. Mukhtar and R.J. Pomerantz, 2000. Human immunodeficiency virus type $1 \mathrm{Vpr}$ induces apoptosis in human neuronal cells. J. Virol., 74: 9717-9726. http://www.ncbi.nlm.nih.gov/pubmed/11000244

14. Turchan, J., C.B. Pocernich, C. Gairola, A. Chauhan and A. Nath et al., 2003. Oxidative stress in HIV demented patients and protection ex vivo with novel antioxidants. Neurology, 60: 307-314. http://www.ncbi.nlm.nih.gov/pubmed/12552050 
15. Dalgleish, A.G., 1985. Human retroviruses. Aust. N. Z. J. Med., 15: 375-385. http://www.ncbi.nlm.nih.gov/pubmed/2998317

16. Kozak, S.L., E.J. Platt, N. Madani, F.E. Ferro Jr, K. Peden and D. Kabat, 1997. CD4, CXCR-4 and CCR-5 dependencies for infections by primary patient and laboratory-adapted isolates of human immunodeficiency virus type 1. J. Virol., 71: 873-882. http://www.pubmedcentral.nih.gov/articlerender.fc gi? $\operatorname{artid}=191134$

17. Al-Harthi, L. and K.A. Roebuck, 1998. Human immunodeficiency virus type- 1 transcription: Role of the 5'-untranslated leader region (review). Int. J. Mol. Med., 1: 875-881. http://www.ncbi.nlm.nih.gov/pubmed/9852310

18. Feinberg, M.B., D. Baltimore and A.D. Frankel, 1991. The role of Tat in the human immunodeficiency virus life cycle indicates a primary effect on transcriptional elongation. Proc. Natl. Acad. Sci. USA., 88: 4045-4049. http://www.pubmedcentral.nih.gov/articlerender.fc gi? artid $=51590$

19. Gaynor, R., 1992. Cellular transcription factors involved in the regulation of HIV-1 gene expression. Aids, 6: 347-363. http://www.ncbi.nlm.nih.gov/pubmed/1616633

20. Golub, E.I., G.R. Li and D.J. Volsky, 1991. Induction of dormant HIV-1 by sodium butyrate: Involvement of the TATA box in the activation of the HIV-1 promoter. Aids, 5: 663-668. http://www.ncbi.nlm.nih.gov/pubmed/1883541

21. Jordan, H.L., A.S. Pereira, M.S. Cohen and A.D. Kashuba, 2001. Domestic cat model for predicting human nucleoside analogue pharmacokinetics in blood and seminal plasma. Antimicrob. Agent. Chemother, 45: 2173-2176. DOI: 10.1128/AAC.45.7.2173-2176.2001

22. Kao, S.Y., A.F. Calman, P.A. Luciw and B.M. Peterlin, 1987. Anti-termination of transcription within the long terminal repeat of HIV-1 by tat gene product. Nature, 330: 489-493. http://www.ncbi.nlm.nih.gov/pubmed/2825027

23. Ladias, J.A., 1994. Convergence of multiple nuclear receptor signaling pathways onto the long terminal repeat of human immunodeficiency virus1. J. Biol. Chem., 269: 5944-5951. http://www.ncbi.nlm.nih.gov/pubmed/8119938

24. Ou, S.H., L.F. Garcia-Martinez, E.J. Paulssen and R.B. Gaynor, 1994. Role of flanking E box motifs in human immunodeficiency virus type 1 TATA element function. J. Virol., 68: 7188-7199. http://jvi.asm.org/cgi/content/abstract/68/11/7188
25. Roebuck, K.A. and M. Saifuddin, 1999. Regulation of HIV-1 transcription. Gene Expr., 8: 67-84. http://www.ncbi.nlm.nih.gov/pubmed/10551796

26. Van Lint, C., S. Emiliani, M. Ott and E. Verdin, 1996. Transcriptional activation and chromatin remodeling of the HIV-1 promoter in response to histone acetylation. EMBO. J., 15: 1112-1120. http://www.ncbi.nlm.nih.gov/pubmed/8605881

27. Zhang, L., C. Waters, J. Nichols and C. Crumpacker, 1992. Inhibition of HIV-1 RNA production by the diphtheria toxin-related IL-2 fusion proteins DAB486IL-2 and DAB389IL-2. J. Acquir. Immune. Defic. Syndr., 5: 1181-1187. http://www.ncbi.nlm.nih.gov/pubmed/1453329?do $\mathrm{pt}=$ Abstract

28. Smith, J.S. and M.J. Roth, 1992. Specificity of human immunodeficiency virus-1 reverse transcriptase-associated ribonuclease $\mathrm{H}$ in removal of the minus-strand primer, tRNA(Lys3). J. Biol. Chem., 267: 15071-15079. http://www.jbc.org/cgi/content/abstract/267/21/15071

29. Calame, A. and C.L. Fawer, 1997. Neurodevelopmental follow-up of children after severe neonatal asphyxia. Pediatr. Pulmonol. Suppl., 16: 254-255.

http://www.ncbi.nlm.nih.gov/pubmed/9443299

30. Gowda, S.D., B.S. Stein, K.S. Steimer and E.G. Engleman, 1989. Expression and processing of human immunodeficiency virus type $1 \mathrm{gag}$ and pol genes by cells infected with a recombinant vaccinia virus. J. Virol., 63: 1451-1454. http://www.pubmedcentral.nih.gov/articlerender.fc gi? artid $=247850$

31. Henderson, A.J., X. Zou and K.L. Calame, 1995. $\mathrm{C} / \mathrm{EBP}$ proteins activate transcription from the human immunodeficiency virus type 1 long terminal repeat in macrophages/monocytes. J. Virol., 69: 5337-5344. http://www.pubmedcentral.nih.gov/articlerender.fc gi? artid=189374

32. Hogan, T.H., M.R. Nonnemacher, F.C. Krebs, A. Henderson and B. Wigdahl, 2003. HIV-1 Vpr binding to HIV-1 LTR C/EBP cis-acting elements and adjacent regions is sequence-specific. Biomed. Pharmacother., 57: 41-48. http://www.ncbi.nlm.nih.gov/pubmed/12642036

33. Hogan, T.H., D.L. Stauff, F.C. Krebs, S. Gartner, S.J. Quiterio and B. Wigdahl, 2003. Structural and functional evolution of human immunodeficiency virus type 1 long terminal repeat CCAAT/enhancer binding protein sites and their use as molecular markers for central nervous system disease progression. J. Neurovirol., 9: 55-68. http://www.ncbi.nlm.nih.gov/pubmed/12587069 
34. Krebs, F.C., M.M. Goodenow and B. Wigdahl, 1997. Neuroglial ATF/CREB factors interact with the human immunodeficiency virus type 1 long terminal repeat. J. Neurovirol., 1: S28-32. http://www.ncbi.nlm.nih.gov/pubmed/9179787

35. McAllister, J.J., D. Phillips, S. Millhouse, J. Conner, T. Hogan, H.L. Ross and B. Wigdahl, 2000. Analysis of the HIV-1 LTR NF-kappaB-proximal Sp site III: Evidence for cell type-specific gene regulation and viral replication. Virology, 274: 262-277. DOI: 10.1006/viro.2000.0476

36. McDougal, J.S., M. Hubbard, J.K. Nicholson, B.M. Jones and R.C. Holman et al., 1985. Immune complexes in the Acquired Immunodeficiency Syndrome (AIDS): Relationship to disease manifestation, risk group and immunologic defect. J. Clin. Immunol., 5: 130-138. http://cat.inist.fr/?aModele=afficheN\&cpsidt=9111311

37. Ross, H.L., S. Gartner, J.C. McArthur, J.R. Corboy, J.J. McAllister, S. Millhouse, B. Wigdahl, 2001. HIV-1 LTR C/EBP binding site sequence configurations preferentially encountered in brain lead to enhanced C/EBP factor binding and increased LTR-specific activity. J. Neurovirol., 7: 235-249. http://www.ncbi.nlm.nih.gov/pubmed/11517398

38. Ross, H.L., M.R. Nonnemacher, T.H. Hogan, S.J. Quiterio, A. Henderson, J.J. McAllister, F.C. Krebs and B. Wigdahl, 2001. Interaction between CCAAT/enhancer binding protein and cyclic AMP response element binding protein 1 regulates human immunodeficiency virus type 1 transcription in cells of the monocyte/macrophage lineage. J. Virol., 75: 1842-1856. DOI: 10.1128/JVI.75.4.1842-1856.2001

39. Burdo, T.H., S. Gartner, D. Mauger and B. Wigdahl, 2004. Region-specific distribution of human immunodeficiency virus type 1 long terminal repeats containing specific configurations of CCAAT/enhancer-binding protein site II in brains derived from demented and nondemented patients. J. Neurovirol., 1: 7-14. http://www.ncbi.nlm.nih.gov/pubmed/14982733

40. Gatignol, A., A. Buckler-White, B. Berkhout and K.T. Jeang, 1991. Characterization of a human TAR RNA-binding protein that activates the HIV-1 LTR. Science, 251: 1597-1600. http://www.ncbi.nlm.nih.gov/pubmed/2011739

41. Sawaya, B.E., K. Khalili, J. Rappaport, D. Serio, W. Chen, A. Srinivasan and S. Amini, 1999. Suppression of HIV-1 transcription and replication by a Vpr mutant. Gene. Ther., 6: 947-950. http://www.ncbi.nlm.nih.gov/pubmed/10505122
42. Brady, J. and F. Kashanchi, 2005. Tat gets the "green" light on transcription initiation. Retrovirology, 2: 69-69. http://www.ncbi.nlm.nih.gov/pubmed/16280076

43. Doppler, C., G. Schalasta, E. Amtmann and G. Sauer, 1992. Binding of NF-kB to the HIV-1 LTR is not sufficient to induce HIV-1 LTR activity. AIDS Res. Hum. Retroviruses, 8: 245-252. http://www.ncbi.nlm.nih.gov/pubmed/1540410

44. Green, M., M. Ishino and P.M. Loewenstein, 1989. Mutational analysis of HIV-1 Tat minimal domain peptides: Identification of trans-dominant mutants that suppress HIV-LTR-driven gene expression. Cell, 58: 215-223. http://www.ncbi.nlm.nih.gov/pubmed/2752420

45. Rice, A.P. and M.B. Mathews, 1988. Transcriptional but not translational regulation of HIV-1 by the tat gene product. Nature, 332: 551-553. http://www.ncbi.nlm.nih.gov/pubmed/2833703

46. Rappaport, J., J. Joseph, S. Croul, G. Alexander, L. Del Valle, S. Amini and K. Khalili, 1999. Molecular pathway involved in HIV-1-induced CNS pathology: Role of viral regulatory protein, Tat. J. Leukoc. Biol., 65: 458-465. http://www.ncbi.nlm.nih.gov/pubmed/10204574

47. Raha, T., S.W. Cheng and M.R. Green, 2005. HIV1 Tat stimulates transcription complex assembly through recruitment of TBP in the absence of TAFs. PLoS. Biol., 3: 44-44. http://www.ncbi.nlm.nih.gov/pubmed/15719058

48. Selby, M.J., E.S. Bain, P.A. Luciw and B.M. Peterlin, 1989. Structure, sequence and position of the stemloop in tar determine transcriptional elongation by tat through the HIV-1 long terminal repeat. Genes Dev., 3: 547-558. http://genesdev.cshlp.org/content/3/4/547.abstract

49. Taylor, J.P. and K. Khalili, 1994. Activation of HIV-1 transcription by Tat in cells derived from the CNS: Evidence for the participation of NFkappa B--a review. Adv. Neuroimmunol., 4: 291-303. http://www.biomedexperts.com/Abstract.bme/7874 398/Activation_of_HIV-

1_transcription_by_Tat_in_cells_derived_from_the _CNS_evidence_for_the_participation_of_NFkappa_B--a

50. Sawaya, B.E., K. Khalili and S. Amini, 1998. Transcription of the human immunodeficiency virus type 1 (HIV-1) promoter in central nervous system cells: effect of YB-1 on expression of the HIV-1 long terminal repeat. J. Gen. Virol., 79: 239-246. http://vir.sgmjournals.org/cgi/content/abstract/79/2/239

51. Nabel, G.J., 1988. Activation of human immunodeficiency virus. J. Lab. Clin. Med., 111: 495-500.

http://www.ncbi.nlm.nih.gov/pubmed/3283280 
52. Nabel, G.J., S.A. Rice, D.M. Knipe and D. Baltimore, 1988. Alternative mechanisms for activation of human immunodeficiency virus enhancer in $\mathrm{T}$ cells. $\quad$ Science, 239: 1299-1302. http://www.sciencemag.org/cgi/content/abstract/23 9/4845/1299

53. Andreoni, M., 2004. Viral phenotype and fitness. New Microbiol., 27: 71-76. http://www.ncbi.nlm.nih.gov/pubmed/15646067

54. Roof, P., M. Ricci, P. Genin, M.A. Montano, M. Essex, M.A. Wainberg, A. Gatignol and J. Hiscott, 2002. Differential regulation of HIV-1 clade-specific B, $\mathrm{C}$ and $\mathrm{E}$ long terminal repeats by NF-kappaB and the Tat transactivator. Virology, 296: 77-83. http://www.ncbi.nlm.nih.gov/pubmed/12036319

55. Bratanich, A.C., C. Liu, J.C. McArthur, T. Fudyk, J.D. Glass, S. Mittoo, G.A. Klassen and C. Power, 1998. Brain-derived HIV-1 tat sequences from AIDS patients with dementia show increased molecular heterogeneity. J. Neurovirol., 4: 387-393. http://www.ncbi.nlm.nih.gov/pubmed/9718130

56. Mayne, M., A.C. Bratanich, P. Chen, F. Rana, A. Nath and C. Power, 1998. HIV-1 tat molecular diversity and induction of TNF-alpha: implications for HIVinduced neurological disease. Neuroimmunomodulation, $\quad$ 5: 184-192. http://www.ncbi.nlm.nih.gov/pubmed/9730685

57. Johnston, J.B., K. Zhang, C. Silva, D.R. Shalinsky, K. Conant, W. Ni, D. Corbett, V.W. Yong and C. Power, 2001. HIV-1 Tat neurotoxicity is prevented by matrix metalloproteinase inhibitors. Ann. Neurol., 49: 230-241. http://cat.inist.fr/?aModele $=$ afficheN\&cpsidt $=887916$

58. Silva, C., K. Zhang, S. Tsutsui, J.K. Holden, M.J. Gill and C. Power, 2003. Growth hormone prevents human immunodeficiency virus-induced neuronal p53 expression. Ann. Neurol., 54: 605-614. http://www.ncbi.nlm.nih.gov/pubmed/14595650

59. Boven, L.A., F. Noorbakhsh, G. Bouma, R. Van der Zee and D.L. Vargas et al., 2007. Brain-derived human immunodeficiency virus-1 Tat exerts differential effects on LTR transactivation and neuroimmune activation. J. Neurovirol., 13: 173-184. http://www.ncbi.nlm.nih.gov/pubmed/17505986

60. Nath, A., K.F. Hauser, V. Wojna, R.M. Booze, W. Maragos and M. Prendergast et al., 2002. Molecular basis for interactions of HIV and drugs of abuse. J. Acquir. Immune. Defic. Syndr., 2: S62-S69. http://www.ncbi.nlm.nih.gov/pubmed/12394784

61. Kaul, M., J. Zheng, S. Okamoto, H.E. Gendelman and S.A. Lipton, 2005. HIV-1 infection and AIDS: Consequences for the central nervous system. Cell Death Differ., 1: 878-892. http://www.ncbi.nlm.nih.gov/pubmed/15832177
62. Zheng, J., M.R. Thylin, R.L. Cotter, A.L. Lopez, A. Ghorpade and Y. Persidsky et al., 2001. HIV-1 infected and immune competent mononuclear phagocytes induce quantitative alterations in neuronal dendritic arbor: Relevance for HIV-1associated dementia. Neurotox Res., 3: 443-459. DOI: 10.1007/BF03033203

63. Hesselgesser, J., D. Taub, P. Baskar, M. Greenberg, J. Hoxie, D.L. Kolson and R. Horuk, 1998. Neuronal apoptosis induced by HIV-1 gp120 and the chemokine SDF-1 alpha is mediated by the chemokine receptor CXCR4. Curr. Biol., 8: 595-598. http://www.ncbi.nlm.nih.gov/pubmed/9601645

64. Kaul, M. and S.A. Lipton, 1999. Chemokines and activated macrophages in HIV gp120-induced neuronal apoptosis. Proc. Natl. Acad. Sci. USA., 96: 8212-8216.

http://www.pubmedcentral.nih.gov/articlerender.fc gi? artid $=22214$

65. Xu, Y., J. Kulkosky, E. Acheampong, G. Nunnari, J. Sullivan and R.J. Pomerantz, 2004. HIV-1-mediated apoptosis of neuronal cells: Proximal molecular mechanisms of HIV-1-induced encephalopathy. Proc. Natl. Acad. Sci. USA., 101: 7070-7075. http://www.ncbi.nlm.nih.gov/pubmed/15103018

66. Meucci, O., A. Fatatis, A.A. Simen, T.J. Bushell, P.W. Gray and R.J. Miller, 1998. Chemokines regulate hippocampal neuronal signaling and gp120 neurotoxicity. Proc. Natl. Acad. Sci. USA., 95: 14500-14505. http://www.ncbi.nlm.nih.gov/pubmed/9826729

67. Davis, C.B., I. Dikic, D. Unutmaz, C.M. Hill and J. Arthos et al., 1997. Signal transduction due to HIV1 envelope interactions with chemokine receptors CXCR4 or CCR5. J. Exp. Med., 186: 1793-1798. http://www.ncbi.nlm.nih.gov/pubmed/9362541

68. Herbein, G., U. Mahlknecht, F. Batliwalla, P. Gregersen and T. Pappas et al., 1998. Apoptosis of CD8+ T cells is mediated by macrophages through interaction of HIV gp120 with chemokine receptor CXCR4. Nature, 395: 189-194. DOI: 10.1038/26026

69. Hesselgesser, J., M. Liang, J. Hoxie, M. Greenberg, L.F. Brass and R. Horuk et al., 1998. Identification and characterization of the CXCR4 chemokine receptor in human $\mathrm{T}$ cell lines: Ligand binding, biological activity and HIV-1 infectivity. J. Immunol., $\quad$ 160: 877-883. http://www.ncbi.nlm.nih.gov/pubmed/9551924

70. Klein, R.S., K.C. Williams, X. Alvarez-Hernandez and S. Westmoreland et al., 1999. Chemokine receptor expression and signaling in macaque and human fetal neurons and astrocytes: Implications for the neuropathogenesis of AIDS. J. Immunol., 163: 1636-1646.

http://www.jimmunol.org/cgi/content/abstract/163/3/1636 
71. Kozak, S.L., S.E. Kuhmann, E.J. Platt and D. Kabat, 1999. Roles of CD4 and coreceptors in binding, endocytosis and proteolysis of gp120 envelope glycoproteins derived from human immunodeficiency virus type 1. J. Biol. Chem., 274: 23499-23507. http://cat.inist.fr/?aModele=afficheN\&cpsidt=10178652

72. Kaul, M., Q. Ma, K.E. Medders, M.K. Desai and S.A. Lipton, 2007. HIV-1 coreceptors CCR5 and CXCR4 both mediate neuronal cell death but CCR5 paradoxically can also contribute to protection. Cell Death Differ., 14: 296-305. http://www.ncbi.nlm.nih.gov/pubmed/16841089

73. Lannuzel, A., P.M. Lledo, H.O. Lamghitnia, J.D. Vincent and M. Tardieu, 1995. HIV-1 envelope proteins 120 and gp160 potentiate NMDA-induced $[\mathrm{Ca} 2+] \mathrm{i}$ increase, alter $[\mathrm{Ca} 2+] \mathrm{i}$ homeostasis and induce neurotoxicity in human embryonic neurons. Eur. J. Neurosci., 7: 22852293. DOI: 10.1111/j.1460-9568.1995.tb00649.x

74. Dreyer, E.B., P.K. Kaiser, J.T. Offermann and S.A. Lipton, 1990. HIV-1 coat protein neurotoxicity prevented by calcium channel antagonists. Science, 248: 364-367.

http://www.ncbi.nlm.nih.gov/pubmed/2326646

75. Mattson, M.P., N.J. Haughey and A. Nath, 2005. Cell death in HIV dementia. Cell Death Differ., 12: 893-904.

http://www.nature.com/cdd/journal/vaop/ncurrent/f ull/4401577a.html

76. Campus, G., A. Lumbau and S.L. Bachisio, 2000. Caries experience and streptococci and lactobacilli salivary levels in 6-8-year-old Sardinians. Int. J. Paediatr. Dent., 10: 306-312. http://www.ncbi.nlm.nih.gov/pubmed/11310244

77. Biard-Piechaczyk, M., V. Robert-Hebmann, V. Richard, J. Roland, R.A. Hipskind and C. Devaux, 2000. Caspase-dependent apoptosis of cells expressing the chemokine receptor CXCR4 is induced by cell membrane-associated human immunodeficiency virus type 1 envelope glycoprotein (gp120). Virology, 268: 329-344. http://www.ncbi.nlm.nih.gov/pubmed/10704341

78. Ullrich, C.K., J.E. Groopman and R.K. Ganju, 2000. HIV-1 gp120- and gp160-induced apoptosis in cultured endothelial cells is mediated by caspases. Blood, 96: 1438-1442. http://www.ncbi.nlm.nih.gov/pubmed/10942389

79. Peng, F., N. Dhillon, S. Callen, H. Yao, S. Bokhari, X. Zhu, H.H. Baydoun and S. Buch, 2008. Plateletderived growth factor protects neurons against gp120-mediated toxicity. J. Neurovirol., 14: 62-72. http://www.ncbi.nlm.nih.gov/pubmed/18300076
80. Haughey, N.J. and M.P. Mattson, 2002. Calcium dysregulation and neuronal apoptosis by the HIV-1 proteins Tat and gp120. J. Acquir. Immune. Defic. Syndr., 31: S55-61. http://cat.inist.fr/?aModele $=$ afficheN\&cpsidt $=1397$ 8804

81. Medina, I., S. Ghose and Y. Ben-Ari, 1999. Mobilization of intracellular calcium stores participates in the rise of $[\mathrm{Ca} 2+] \mathrm{i}$ and the toxic actions of the HIV coat protein GP120. Eur. J. Neurosci., $\quad 11$ : 1167-1178. http://www.ncbi.nlm.nih.gov/pubmed/10103113

82. Lei, S.Z., Z.H . Pan, S.K. Aggarwal, H.S. Chen, J. Hartman, N.J. Sucher and S.A. Lipton, 1992. Effect of nitric oxide production on the redox modulatory site of the NMDA receptor-channel complex. Neuron, 8: 1087-1099. http://www.ncbi.nlm.nih.gov/pubmed/1376999

83. Lipton, S.A., N.J. Sucher, P.K. Kaiser and E.B. Dreyer, 1991. Synergistic effects of HIV coat protein and NMDA receptor-mediated neurotoxicity. Neuron, 7: 111-118. http://www.ncbi.nlm.nih.gov/pubmed/1676893

84. Williams, S.B., T.P. Flanigan, A.W. Artenstein, T.C. VanCott, D. Smith, K. Mayer and R.A. Koup, 1999. CCR5 genotype and human immunodeficiency virus (HIV)-specific mucosal antibody in seronegative women at high risk for HIV infection. J. Infect. Dis., 179: 1310-1312. http://www.biomedexperts.com/Abstract.bme/1019 1415/CCR5_genotype_and_human_immunodeficie ncy_virus_HIV_-

specific_mucosal_antibody_in_seronegative_wom en_at_high_risk_for_HI

85. Bando, Y., T. Katayama, M. Taniguchi, T. Ishibashi, N. Matsuo, S. Ogawa and M. Tohyama, 2005. RA410/Sly1 suppresses MPP+ and 6hydroxydopamine-induced cell death in SH-SY5Y cells. Neurobiol. Dis., 18: 143-151. http://www.ncbi.nlm.nih.gov/pubmed/15649705

86. Wang, Z., O. Pekarskaya, M. Bencheikh, W. Chao and D.J. Volsky et al., 2003. Reduced expression of glutamate transporter EAAT2 and impaired glutamate transport in human primary astrocytes exposed to HIV-1 or gp120. Virology, 312: 60-73.

87. Galey, D., K. Becker, N. Haughey, A. Kalehua and A. Nath et al., 2003. Differential transcriptional regulation by human immunodeficiency virus type 1 and gp120 in human astrocytes. J. Neurovirol., 9: 358-371.

http://www.ncbi.nlm.nih.gov/pubmed/12775419 
88. Su, Z.Z., D.C. Kang, Y. Chen, O. Pekarskaya, W. Chao, D.J. Volsky and P.B. Fisher, 2002. Identification and cloning of human astrocyte genes displaying elevated expression after infection with HIV-1 or exposure to HIV-1 envelope glycoprotein by rapid subtraction hybridization, RaSH. Oncogene, 21: 3592-3602.

http://www.nature.com/onc/journal/v21/n22/abs/12 05445a.html

89. Kort, J.J., 1998. Impairment of excitatory amino acid transport in astroglial cells infected with the human immunodeficiency virus type 1. AIDS Res. Hum. Retroviruses, 14: 1329-1339. http://www.ncbi.nlm.nih.gov/pubmed/9788674

90. Adamson, D.C., J.C. McArthur, T.M. Dawson and V.L. Dawson, 1999. Rate and severity of HIVassociated dementia (HAD): Correlations with Gp41 and iNOS. Mol. Med., 5: 98-109. http://www.pubmedcentral.nih.gov/articlerender.fc gi artid=2230416

91. Adamson, D.C., B. Wildemann, M. Sasaki, J.D. Glass and V.L. Dawson et al., 1996. Immunologic NO synthase: Elevation in severe AIDS dementia and induction by HIV-1 gp41. Science, 274: 1917-1921. http://cat.inist.fr/?aModele $=$ afficheN\&cpsidt $=2534954$

92. Sung, J.H., S.A. Shin, H.K. Park, R.C. Montelaro and Y.H. Chong, 2001. Protective effect of glutathione in HIV-1 lytic peptide 1-induced cell death in human neuronal cells. J. Neurovirol., 7: 454-465.

http://www.ncbi.nlm.nih.gov/pubmed/11582518

93. Huang, M.B., O. Weeks, L.J. Zhao, M. Saltarelli and V.C. Bond, 2000. Effects of extracellular human immunodeficiency virus type $1 \mathrm{vpr}$ protein in primary rat cortical cell cultures. J. Neurovirol., 6: 202-220.

http://cat.inist.fr/?aModele=afficheN\&cpsidt=1392756

94. Piller, S.C., P. Jans, P.W. Gage and D.A. Jans, 1998. Extracellular HIV-1 virus protein $R$ causes a large inward current and cell death in cultured hippocampal neurons: implications for AIDS pathology. Proc. Natl. Acad. Sci. USA., 95: 4595-4600. http://cat.inist.fr/?aModele $=$ afficheN\&cpsidt $=1040$ 7323

95. Pomerantz, R.J., 2004. Effects of HIV-1 Vpr on neuroinvasion and neuropathogenesis. DNA Cell Biol., 23: 227-238. http://www.ncbi.nlm.nih.gov/pubmed/15142380

96. Emerman, M., 1996. HIV-1, Vpr and the cell cycle. Curr. Biol., 6: 1096-1103. http://direct.bl.uk/bld/PlaceOrder.do?UIN=020191 296\&ETOC $=$ RN\&from $=$ searchengine
97. He, J., S. Choe, R. Walker, P. Di Marzio, D.O. Morgan and N.R. Landau, 1995. Human immunodeficiency virus type 1 viral protein $\mathrm{R}(\mathrm{Vpr})$ arrests cells in the G2 phase of the cell cycle by inhibiting p34cdc2 activity. J. Virol., 69: 6705-6711. http://www.pubmedcentral.nih.gov/articlerender.fc gi? $\operatorname{artid}=189580$

98. Heinzinger, N.K., M.I. Bukinsky, S.A. Haggerty, A.M. Ragland and M. Emerman, 1994. The Vpr protein of human immunodeficiency virus type 1 influences nuclear localization of viral nucleic acids in nondividing host cells. Proc. Natl. Acad. Sci. USA., 91: 7311-7315. http://www.ncbi.nlm.nih.gov/pubmed/8041786

99. Levy, D.N., Y. Refaeli, R.R. MacGregor and D.B. Weiner, 1994. Serum Vpr regulates productive infection and latency of human immunodeficiency virus type 1. Proc. Natl. Acad. Sci. USA., 91: 10873-10877.

http://www.pubmedcentral.nih.gov/articlerender.fc gi? artid $=45128$

100.Connor, R.I., B.K. Chen, S. Choe and N.R. Landau, 1995. Vpr is required for efficient replication of human immunodeficiency virus type-1 in mononuclear phagocytes. Virology, 206: 935-944. http://www.ncbi.nlm.nih.gov/pubmed/7531918

101.Gallay, P., V. Stitt, C. Mundy, M. Oettinger and D. Trono, 1996. Role of the karyopherin pathway in human immunodeficiency virus type 1 nuclear import. J. Virol., 70: 1027-1032. http://www.pubmedcentral.nih.gov/articlerender.fc gi?artid=189908

102.Bartz, S.R., M.E. Rogel and M. Emerman, 1996. Human immunodeficiency virus type 1 cell cycle control: $\mathrm{Vpr}$ is cytostatic and mediates G2 accumulation by a mechanism which differs from DNA damage checkpoint control. J. Virol., 70: 2324-2331.

http://www.pubmedcentral.nih.gov/articlerender.fc gi? artid=190074

103.Huard, S., R.T. Elder, D. Liang, G. Li and R.Y. Zhao, 2008. Human immunodeficiency virus type $1 \mathrm{Vpr}$ induces cell cycle G2 arrest through Srk1/MK2mediated phosphorylation of Cdc25. J. Virol., 82:

2904-2917. http://www.pubmedcentral.nih.gov/articlerender.fc gi? artid=2259012

104.Jowett, J.B., V. Planelles, B. Poon, N.P. Shah, M.L. Chen and I.S. Chen, 1995. The human immunodeficiency virus type $1 \mathrm{vpr}$ gene arrests infected $\mathrm{T}$ cells in the $\mathrm{G} 2+\mathrm{M}$ phase of the cell cycle. J. Virol., 69: 6304-6313. http://jvi.asm.org/cgi/content/abstract/69/10/6304 
105.Planelles, V., F. Bachelerie, J.B. Jowett, A. Haislip and Y. Xie et al., 1995. Fate of the human immunodeficiency virus type 1 provirus in infected cells: A role for vpr. J. Virol., 69: 5883-5889. http://www.pubmedcentral.nih.gov/articlerender.fc gi? $\operatorname{artid}=189467$

106.Poon, B., J.B. Jowett, S.A. Stewart, R.W. Armstrong, G.M. Rishton and I.S. Chen, 1997. Human immunodeficiency virus type $1 \mathrm{vpr}$ gene induces phenotypic effects similar to those of the DNA alkylating agent, nitrogen mustard. J. Virol., 71: 3961-3971.

http://www.pubmedcentral.nih.gov/articlerender.fc gi ?artid $=191548$

107.Re, F., D. Braaten, E.K. Franke and J. Luban, 1995. Human immunodeficiency virus type $1 \mathrm{Vpr}$ arrests the cell cycle in G2 by inhibiting the activation of p34cdc2-cyclin B. J. Virol., 69: 6859-6864. http://www.pubmedcentral.nih.gov/articlerender.fc gi? artid=189600

108.Rogel, M.E., L.I. Wu and M. Emerman, 1995. The human immunodeficiency virus type 1 vpr gene prevents cell proliferation during chronic infection. J. Virol., 69: 882-888. http://www.pubmedcentral.nih.gov/articlerender.fc gi? artid=188655

109.Levy, D.N., L.S. Fernandes, W.V. Williams and D.B. Weiner, 1993. Induction of cell differentiation by human immunodeficiency virus 1 vpr. Cell, 72: 541-550. http://www.ncbi.nlm.nih.gov/pubmed/8440020

110.Poon, B., K. Grovit-Ferbas, S.A. Stewart and I.S. Chen, 1998. Cell cycle arrest by Vpr in HIV-1 virions and insensitivity to antiretroviral agents. Science, 281: 266-269. http://cat.inist.fr/?aModele $=$ afficheN\&cpsidt $=2376$ 135

111.Goh, W.C., M.E. Rogel, C.M. Kinsey, S.F. Michael and P.N. Fultz et al., 1998. HIV-1 Vpr increases viral expression by manipulation of the cell cycle: A mechanism for selection of $\mathrm{Vpr}$ in vivo. Nat. Med., 4: 65-71. http://www.ncbi.nlm.nih.gov/pubmed/9427608

112.Paxton, W., R.I. Connor and N.R. Landau, 1993. Incorporation of $\mathrm{Vpr}$ into human immunodeficiency virus type 1 virions: Requirement for the p6 region of gag and mutational analysis. J. Virol., 67: 7229-7237. http://www.pubmedcentral.nih.gov/articlerender.fc gi? artid=238185

113.Lu, Y.L., P. Spearman and L. Ratner, 1993. Human immunodeficiency virus type 1 viral protein $R$ localization in infected cells and virions. J. Virol., 67: 6542-6550.

http://www.pubmedcentral.nih.gov/articlerender.fc gi artid=238091
114.Sherman, M.P., C.M. De Noronha, M.I. Heusch, S. Greene and W.C. Greene, 2001. Nucleocytoplasmic shuttling by human immunodeficiency virus type 1 Vpr. J. Virol., 75: 1522-1532. http://www.ncbi.nlm.nih.gov/pubmed/11152524

115.Bukrinsky, M. and Y. Zhao, 2004. Heat-shock proteins reverse the $\mathrm{G} 2$ arrest caused by $\mathrm{HIV}-1$ viral protein R. DNA Cell Biol., 23: 223-225. DOI: 10.1089/104454904773819806

116.Popov, S., M. Rexach, L. Ratner, G. Blobel and M. Bukrinsky, 1998. Viral protein $\mathrm{R}$ regulates docking of the HIV-1 preintegration complex to the nuclear pore complex. J. Biol. Chem., 273: 13347-13352. http://www.ncbi.nlm.nih.gov/pubmed/9582382

117.Popov, S., M. Rexach, G. Zybarth, N. Reiling, M.A. Lee and M. Bukrinsky et al., 1998. Viral protein $\mathrm{R}$ regulates nuclear import of the HIV-1 pre-integration complex. EMBO. J., 17: 909-917. http://www.pubmedcentral.nih.gov/articlerender.fc gi?artid=1170440

118.Bouyac-Bertoia, M., J.D. Dvorin, R.A. Fouchier, Y. Jenkins and M.H. Malim et al., 2001. HIV-1 infection requires a functional integrase NLS. Mol. Cell., $\quad 7$ : 1025-1035. http://www.ncbi.nlm.nih.gov/pubmed/11389849

119.Eckstein, D.A., M.P. Sherman, M.L. Penn, P.S. Chin and M.A. Goldsmith et al., 2001. HIV-1 Vpr enhances viral burden by facilitating infection of tissue macrophages but not nondividing CD4+ T cells. J. Exp. Med., 194: 1407-1419. http://www.ncbi.nlm.nih.gov/pubmed/11714748

120. Sherman, M.P., C.M. de Noronha, L.A. Eckstein, J. Hataye and W.C. Greene et al., 2003. Nuclear export of $\mathrm{Vpr}$ is required for efficient replication of human immunodeficiency virus type 1 in tissue macrophages. J. Virol., 77: 7582-7589. http://cat.inist.fr/?aModele $=$ afficheN\&cpsidt $=14886735$

121.Fouchier, R.A., B.E. Meyer, J.H. Simon, U. Fischer and A.V. Albright et al, 1998. Interaction of the human immunodeficiency virus type $1 \mathrm{Vpr}$ protein with the nuclear pore complex. J. Virol., 72: 6004-6013. http://www.ncbi.nlm.nih.gov/pubmed/9621063

122. Vodicka, M.A., D.M. Koepp, P.A. Silver and M. Emerman, 1998. HIV-1 Vpr interacts with the nuclear transport pathway to promote macrophage infection. Genes Dev., 12: 175-185. http://www.ncbi.nlm.nih.gov/pubmed/9436978

123.Jenkins, Y., M. McEntee, K. Weis and W.C. Greene, 1998. Characterization of HIV-1 vpr nuclear import: Analysis of signals and pathways. J. Cell Biol., 143: 875-885. http://www.pubmedcentral.nih.gov/articlerender.fc gi? artid=2132945 
124.Karni, O., A. Friedler, N. Zakai, C. Gilon and A. Loyter, 1998. A peptide derived from the Nterminal region of HIV-1 $\mathrm{Vpr}$ promotes nuclear import in permeabilized cells: Elucidation of the NLS region of the Vpr. FEBS Lett., 429: 421-425. http://www.ncbi.nlm.nih.gov/pubmed/9662462

125.Di Marzio, P., S. Choe, M. Ebright, R. Knoblauch and N.R. Landau, 1995. Mutational analysis of cell cycle arrest, nuclear localization and virion packaging of human immunodeficiency virus type 1 Vpr. J. Virol., 69: 7909-7916. http://www.pubmedcentral.nih.gov/articlerender.fc gi? $\operatorname{artid}=189735$

126. Macreadie, I.G., L.A. Castelli, D.R. Hewish, A. Kirkpatrick, A.C. Ward and A.A. Azad, 1995. A domain of human immunodeficiency virus type 1 Vpr containing repeated $\mathrm{H}(\mathrm{S} / \mathrm{F}) \mathrm{RIG}$ amino acid motifs causes cell growth arrest and structural defects. Proc. Nat. Acad. Sci. USA., 92: 2770-2774. http://www.pnas.org/content/92/7/2770.abstract

127. Mahalingam, S., R.G. Collman, M. Patel, C.E. Monken and A. Srinivasan, 1995. Role of the conserved dipeptide Gly75 and Cys76 on HIV-1 $\mathrm{Vpr}$ function. Virology, 210: 495-500. http://www.ncbi.nlm.nih.gov/pubmed/7618286

128. Mahalingam, S., S.A. Khan, M.A. Jabbar, C.E. Monken, R.G. Collman and A. Srinivasan, 1995. Identification of residues in the N-terminal acidic domain of HIV-1 Vpr essential for virion incorporation. Virology, 207: 297-302. http://www.ncbi.nlm.nih.gov/pubmed/7871742

129. Mahalingam, S., M. Patel, R.G. Collman and A. Srinivasan, 1995. The carboxy-terminal domain is essential for stability and not for virion incorporation of HIV-1 Vpr into virus particles. Virology, 214: 647-652. http://linkinghub.elsevier.com/retrieve/pii/S004268 2285700797

130.Stewart, S.A., B. Poon, J.B. Jowett and I.S. Chen, 1997. Human immunodeficiency virus type $1 \mathrm{Vpr}$ induces apoptosis following cell cycle arrest. J. Virol., 71: 5579-5592. http://jvi.asm.org/cgi/content/abstract/71/7/5579

131.Stewart, S.A., B. Poon, J.Y. Song and I.S. Chen, 2000. Human immunodeficiency virus type $1 \mathrm{vpr}$ induces apoptosis through caspase activation. J. Virol., 74: 3105-3111. http://www.ncbi.nlm.nih.gov/pubmed/10708425

132. Kulkosky, J., A. Laptev, S. Shetty, A. Srinivasan, M. BouHamdan, D.J. Prockop and R.J. Pomerantz, 1999. Human immunodeficiency virus type 1 Vpralters bone marrow cell function. Blood, 93: 1906-1915.

http://www.ncbi.nlm.nih.gov/pubmed/10068663
133.Cohen, G.B., R.T. Gandhi, D.M. Davis, O. Mandelboim, B.K. Chen, J.L. Strominger and D. Baltimore, 1999. The selective downregulation of class I major histocompatibility complex proteins by HIV-1 protects HIV-infected cells from NK cells. Immunity, 10: 661-671. http://www.ncbi.nlm.nih.gov/pubmed/10403641

134.Garcia, J.V. and J.L. Foster, 1996. Structural and functional correlates between HIV-1 and SIV Nef isolates. Virology, 226: 161-166. http://cat.inist.fr/?aModele=afficheN\&cpsidt=10710281

135.Schwartz, O., V. Marechal, S. Le Gall, F. Lemonnier and J.M. Heard, 1996. Endocytosis of major histocompatibility complex class I molecules is induced by the HIV-1 Nef protein. Nat. Med., 2: 338-342.

http://www.ncbi.nlm.nih.gov/pubmed/8612235

136.Hrecka, K., T. Swigut, M. Schindler, F. Kirchhoff and J. Skowronski, 2005. Nef proteins from diverse groups of primate lentiviruses downmodulate CXCR4 to inhibit migration to the chemokine stromal derived factor 1. J. Virol., 79: 10650-10659. http://www.ncbi.nlm.nih.gov/pubmed/16051857

137. Madrid, R., K. Janvier, D. Hitchin, J. Day, S. Coleman and S. Benichou et al., 2005. Nefinduced alteration of the early/recycling endosomal compartment correlates with enhancement of HIV1 infectivity. J. Biol. Chem., 280: 5032-5044. http://www.jbc.org/cgi/content/abstract/280/6/5032

138.Michel, N., I. Allespach, S. Venzke, O.T. Fackler and O.T. Keppler, 2005. The Nef protein of human immunodeficiency virus establishes superinfection immunity by a dual strategy to downregulate cellsurface CCR5 and CD4. Curr. Biol., 15: 714-723. http://linkinghub.elsevier.com/retrieve/pii/S096098 2205002319

139.Michel, N., K. Ganter, S. Venzke, J. Bitzegeio, O.T. Fackler and O.T. Keppler, 2006. The Nef protein of human immunodeficiency virus is a broad-spectrum modulator of chemokine receptor cell surface levels that acts independently of classical motifs for receptor endocytosis and Galphai signaling. Mol. Biol. Cell, 17: 3578-3590. http://www.molbiolcell.org/cgi/content/abstract/17/8/3578

140.Stove, V., I. Van de Walle, E. Naessens, E. Coene, C. Stove, J. Plum and B. Verhasselt, 2005. Human immunodeficiency virus Nef induces rapid internalization of the T-cell coreceptor CD8alphabeta. J. Virol., 79: 11422-11433. http://www.ncbi.nlm.nih.gov/pubmed/16103193

141.Swigut, T., N. Shohdy and J. Skowronski, 2001. Mechanism for down-regulation of CD28 by Nef. EMBO. J., 20 : 1593-1604. http://www.ncbi.nlm.nih.gov/pubmed/11285224 
142.Venzke, S., N. Michel, I. Allespach, O.T. Fackler and O.T. Keppler, 2006. Expression of Nef downregulates CXCR4, the major coreceptor of human immunodeficiency virus, from the surfaces of target cells and thereby enhances resistance to superinfection. J. Virol., 80: 11141-11152. http://jvi.asm.org/cgi/content/abstract/80/22/11141?etoc

143.Arganaraz, E.R., M. Schindler, F. Kirchhoff, M.J. Cortes and J. Lama, 2003. Enhanced CD4 down-modulation by late stage HIV-1 nef alleles is associated with increased Env incorporation and viral replication. J. Biol. Chem., 278: 33912-33919.

http://gateway.nlm.nih.gov/MeetingAbstracts/1022 62631.html

144.Cortes, M.J., F. Wong-Staal and J. Lama, 2002. Cell surface CD4 interferes with the infectivity of HIV-1 particles released from $\mathrm{T}$ cells. J. Biol. Chem., 277: 1770-1779. http://www.ncbi.nlm.nih.gov/pubmed/11704677

145.Schiavoni, I., S. Trapp, A.C. Santarcangelo, V. Piacentini, K. Pugliese, A. Baur and M. Federico, 2004. HIV-1 Nef enhances both membrane expression and virion incorporation of Env products. A model for the Nef-dependent increase of HIV-1 infectivity. J. Biol. Chem., 279: 22996-23006.

http://direct.bl.uk/bld/PlaceOrder.do?UIN=150824

276\&ETOC $=$ RN\&from $=$ searchengine

146.Bukovsky, A.A., T. Dorfman, A. Weimann and H.G. Gottlinger, 1997. Nef association with human immunodeficiency virus type 1 virions and cleavage by the viral protease. J. Virol., 71: 1013-1018.

http://www.pubmedcentral.nih.gov/articlerender.fc gi? artid=191151

147.Forshey, B.M. and C. Aiken, 2003. Disassembly of human immunodeficiency virus type 1 cores in vitro reveals association of Nef with the subviral ribonucleoprotein complex. J. Virol., 77: 4409-4414. DOI: 10.1128/JVI.77.7.44094414.2003

148.Kotov, A., J. Zhou, P. Flicker and C. Aiken, 1999. Association of Nef with the human immunodeficiency virus type 1 core. J. Virol., 73: 8824-8830.

http://www.ncbi.nlm.nih.gov/pubmed/10482638

149.Welker, R., H. Hohenberg, U. Tessmer, C. Huckhagel and H.G. Krausslich, 2000. Biochemical and structural analysis of isolated mature cores of human immunodeficiency virus type 1. J. Virol., 74: 1168-1177. http://www.ncbi.nlm.nih.gov/pubmed/10627527
150.Chakrabarti, L.A., K.J. Metzner, T. Ivanovic, H. Cheng, J. Louis-Virelizier, R.I. Connor and C. Cheng-Mayer, 2003. A truncated form of Nef selected during pathogenic reversion of simian immunodeficiency virus SIVmac239Deltanef increases viral replication. J. Virol., 77: 1245-1256. http://www.ncbi.nlm.nih.gov/pubmed/12502842

151.Deacon, N.J., A. Tsykin, A. Solomon, K. Smith and J. Mills, 1995. Genomic structure of an attenuated quasi species of HIV-1 from a blood transfusion donor and recipients. Science, 270: 988-991.

http://www.ncbi.nlm.nih.gov/pubmed/7481804

152.Gorry, P.R., M. Churchill, J. Learmont, C. Cherry, W.B. Dyer, S.L. Wesselingh and J.S. Sullivan, 2007. Replication-dependent pathogenicity of attenuated nef-deleted HIV-1 in vivo. J. Acquir Immune Defic. Syndr., 46: 390-394. http://www.ncbi.nlm.nih.gov/pubmed/17993857

153.Gorry, P.R., D.A. McPhee, E. Verity, W.B. Dyer, S.L. Wesselingh and M.J. Churchill, 2007. Pathogenicity and immunogenicity of attenuated, nef-deleted HIV-1 strains in vivo. Retrovirology, 4: 66-66. http://www.ncbi.nlm.nih.gov/pubmed/17888184

154.Kestler, H.W., 3rd, D.J. Ringler, K. Mori, D.L. Panicali, P.K. Sehgal, M.D. Daniel and R.C. Desrosiers, 1991. Importance of the nef gene for maintenance of high virus loads and for development of AIDS. Cell, 65: 651-662. http://www.ncbi.nlm.nih.gov/pubmed/2032289

155.Kirchhoff, F., T.C. Greenough, D.B. Brettler, J.L. Sullivan and R.C. Desrosiers, 1995. Brief report: Absence of intact nef sequences in a longterm survivor with nonprogressive HIV-1 infection. N. Engl. J. Med., 332: 228-232. http://www.ncbi.nlm.nih.gov/pubmed/7808489

156.Sawai, E.T., M.S. Hamza, M. Ye, K.E. Shaw and P.A. Luciw, 2000. Pathogenic conversion of live attenuated simian immunodeficiency virus vaccines is associated with expression of truncated Nef. J. Virol., 74: 2038-2045. http://www.ncbi.nlm.nih.gov/pubmed/10644378

157.Aiken, C. and D. Trono, 1995. Nef stimulates human immunodeficiency virus type 1 proviral DNA synthesis. J. Virol., 69: 5048-5056. http://www.pubmedcentral.nih.gov/articlerender.fc gi? artid=189322

158.Bertsch, C., D. Cluet, C. Beyer, L. Gloeckler, A. Cecile, J.P. Gut and A.M. Aubertin, 2002. Properties of a chimeric simian-human immunodeficiency virus expressing an hybrid HIV1 Nef/SIV mac Nef protein. Arch. Virol., 147: 1963-1975. DOI: 10.1007/s00705-002-0857-8 
159.Schaeffer, E., R. Geleziunas and W.C. Greene, 2001. Human immunodeficiency virus type $1 \mathrm{Nef}$ functions at the level of virus entry by enhancing cytoplasmic delivery of virions. J. Virol., 75: 2993-3000.

http://www.ncbi.nlm.nih.gov/pubmed/11222724

160.Campbell, E.M., R. Nunez and T.J. Hope, 2004. Disruption of the actin cytoskeleton can complement the ability of Nef to enhance human immunodeficiency virus type 1 infectivity. J. Virol., 78: 5745-5755. http://direct.bl.uk/bld/PlaceOrder.do?UIN=150805 $604 \&$ ETOC $=$ RN \& from $=$ searchengine

161.Fujii, Y., K. Otake, M. Tashiro and A. Adachi, 1996. Human immunodeficiency virus type $1 \mathrm{Nef}$ protein on the cell surface is cytocidal for human CD4+ T cells. FEBS Lett., 393: 105-108. http://linkinghub.elsevier.com/retrieve/pii/0014579 396008629

162.Kramer-Hammerle, S., A. Hahn, R. Brack-Werner and T. Werner, 2005. Elucidating effects of longterm expression of HIV-1 Nef on astrocytes by microarray, promoter and literature analyses. Gene, 358: 31-38.

http://cat.inist.fr/?aModele=afficheN\&cpsidt=17117109

163.Trillo-Pazos, G., E. McFarlane-Abdulla, I.C. Campbell, G.J. Pilkington and I.P. Everall, 2000. Recombinant nef HIV-IIIB protein is toxic to human neurons in culture. Brain Res., 864: 315-326. http://www.ncbi.nlm.nih.gov/pubmed/10802040

164.Garry, R.F., J.J. Kort, F. Koch-Nolte and G. Koch, 1991. Similarities of viral proteins to toxins that interact with monovalent cation channels. AIDS, 5: 1381-1384. http://www.ncbi.nlm.nih.gov/pubmed/1722677

165.Werner, T., S. Ferroni, T. Saermark, R. BrackWerner, R.B. Banati and V. Erfle, 1991. HIV-1 Nef protein exhibits structural and functional similarity to scorpion peptides interacting with $\mathrm{K}+$ channels. $\quad$ AIDS, 5: 1301-1308. http://www.ncbi.nlm.nih.gov/pubmed/1768378

166. Speth, C., T. Schabetsberger, I. Mohsenipour and G. Stockl et al., 2002. Mechanism of human immunodeficiency virus-induced complement expression in astrocytes and neurons. J. Virol., 76: 3179-3188. http://cat.inist.fr/?aModele $=$ afficheN\&cpsidt $=13548976$

167.Kumar, A., S. Dhawan, A. Mukhopadhyay and B.B. Aggarwal, 1999. Human immunodeficiency virus-1-tat induces matrix metalloproteinase-9 in monocytes through protein tyrosine phosphatasemediated activation of nuclear transcription factor NF-kappaB. FEBS. Lett., 462: 140-144. http://linkinghub.elsevier.com/retrieve/pii/S001457 9399014878
168.McManus, C.M., K. Weidenheim, S.E. Woodman, J. Nunez, J. Hesselgesser, A. Nath and J.W. Berman, 2000. Chemokine and chemokinereceptor expression in human glial elements: Induction by the HIV protein, Tat and chemokine autoregulation. Am. J. Pathol., 156: 1441-1453. http://www.pubmedcentral.nih.gov/articlerender.fc gi? artid= 1876886

169.Del Valle, L., S. Croul, S. Morgello, S. Amini, J. Rappaport and K. Khalili, 2000. Detection of HIV-1 Tat and JCV capsid protein, VP1, in AIDS brain with progressive multifocal leukoencephalopathy. J. Neurovirol., 6: 221-228. http://www.ncbi.nlm.nih.gov/pubmed/10878711

170.Song, L., A. Nath, J.D. Geiger, A. Moore and S. Hochman, 2003. Human immunodeficiency virus type 1 Tat protein directly activates neuronal $\mathrm{N}$-methyl-D-aspartate receptors at an allosteric zinc-sensitive site. J. Neurovirol., 9: 399-403. http://www.ncbi.nlm.nih.gov/pubmed/12775422

171. King, J.E., E.A. Eugenin, C.M. Buckner and J.W. Berman, 2006. HIV tat and neurotoxicity. Microbes Infect., 8: 1347-1357. http://www.ncbi.nlm.nih.gov/pubmed/16697675

172.Li, W., Y. Huang, R. Reid, J. Steiner, T. MalpicaLlanos and A. Nath et al., 2008. NMDA receptor activation by HIV-Tat protein is clade dependent. J. Neurosci., 28: 12190-12198. http://www.ncbi.nlm.nih.gov/pubmed/19020013

173.Cepeda, C. and M.S. Levine, 1998. Dopamine and $\mathrm{N}$-methyl-D-aspartate receptor interactions in the neostriatum. Dev. Neurosci., 20: 1-18. DOI: $10.1159 / 000017294$

174.Cepeda, C. and M.S. Levine, 2006. Where do you think you are going? The NMDA-D1 receptor trap. Sci. STKE., 333: 20-20. DOI: 10.1126/stke.3332006pe20

175.Lee, F.J. and F. Liu, 2004. Direct interactions between NMDA and D1 receptors: A tale of tails. Biochem. Soc. Trans., 32: 1032-1036. http://www.ionchannels.org/showabstract.php?pmi $\mathrm{d}=15506956$

176.Lezcano, N. and C. Bergson, 2002. D1/D5 dopamine receptors stimulate intracellular calcium release in primary cultures of neocortical and hippocampal neurons. J. Neurophysiol., 87: 2167-2175. http://www.ncbi.nlm.nih.gov/pubmed/11929934

177.Missale, C., C. Fiorentini, C. Busi, G. Collo and P.F. Spano, 2006. The NMDA/D1 receptor complex as a new target in drug development. Curr. Top Med. Chem., 6: 801-808. http://www.ncbi.nlm.nih.gov/pubmed/16719818 
178.Pei, L., F.J. Lee, A. Moszczynska, B. Vukusic and F. Liu, 2004. Regulation of dopamine D1 receptor function by physical interaction with the NMDA receptors. J. Neurosci., 24: 1149-1158. http://www.ncbi.nlm.nih.gov/pubmed/14762133

179.Hudson, L., J. Liu, A. Nath, M. Jones, R. Raghavan, O. Narayan, D. Male and I. Everall, 2000. Detection of the human immunodeficiency virus regulatory protein tat in CNS tissues. J. Neurovirol., 6 : 145-155. http://www.ncbi.nlm.nih.gov/pubmed/10822328

180.Banks, W.A., S.M. Robinson and A. Nath, 2005. Permeability of the blood-brain barrier to HIV-1 Tat. Exp. Neurol., 193: 218-227. http://linkinghub.elsevier.com/retrieve/pii/S001448 8604004613

181.Eugenin, E.A., T.G. D'Aversa, L. Lopez, T.M. Calderon and J.W. Berman, 2003. MCP-1 (CCL2) protects human neurons and astrocytes from NMDA or HIV-tat-induced apoptosis. J. Neurochem., 85: 1299-1311. http://www.ncbi.nlm.nih.gov/pubmed/12753088

182.Haughey, N.J., A. Nath, M.P. Mattson, J.T. Slevin and J.D. Geiger, 2001. HIV-1 Tat through phosphorylation of NMDA receptors potentiates glutamate excitotoxicity. J. Neurochem., 78: 457-467. http://cat.inist.fr/?aModele $=$ afficheN\&cpsidt $=1409$ 4389

183.Nath, A., C. Anderson, M. Jones, W. Maragos, R. Booze, C. Mactutus, J. Bell, K.F. Hauser abd M. Mattson, 2000. Neurotoxicity and dysfunction of dopaminergic systems associated with AIDS dementia. J. Psychopharmacol., 14: 222-227. http://www.ncbi.nlm.nih.gov/pubmed/11106300

184.Bruce-Keller, A.J., A. Chauhan, F.O. Dimayuga, J. Gee, J.N. Keller and A. Nath, 2003. Synaptic transport of human immunodeficiency virus-Tat protein causes neurotoxicity and gliosis in rat brain. J. Neurosci., 23: 8417-8422. http://www.ncbi.nlm.nih.gov/pubmed/12968004

185.Albini, A., R. Soldi, D. Giunciuglio, E. Giraudo, R. Benelli, L. Primo and F. Bussolino et al., 1996. The angiogenesis induced by HIV-1 tat protein is mediated by the Flk-1/KDR receptor on vascular endothelial cells. Nat. Med., 2: 1371-1375. http://www.ncbi.nlm.nih.gov/pubmed/8946838

186.Ghezzi, S., D.M. Noonan, M.G. Aluigi, G. Vallanti, M. Cota and A. Albini, 2000. Inhibition of CXCR4-dependent HIV-1 infection by extracellular HIV-1 Tat. Biochem. Biophys. Res. Commun., 270: 992-996. http://www.ncbi.nlm.nih.gov/pubmed/10772939
187.Liu, Y., M. Jones, C.M. Hingtgen, G. Bu, N. Laribee and J.J. He et al., 2000. Uptake of HIV1 tat protein mediated by low-density lipoprotein receptor-related protein disrupts the neuronal metabolic balance of the receptor ligands. Nat. Med., 6: 1380-1387. DOI: 10.1038/82199

188.Wadia, J.S., R.V. Stan and S.F. Dowdy, 2004. Transducible TAT-HA fusogenic peptide enhances escape of TAT-fusion proteins after lipid raft macropinocytosis. Nat. Med., 10: 310-315. DOI: $10.1038 / \mathrm{nm} 996$

189.Conant, K., A. Garzino-Demo, A. Nath, J.C. McArthur and E.O. Major et al., 1998. Induction of monocyte chemoattractant protein- 1 in HIV-1 Tat-stimulated astrocytes and elevation in AIDS dementia. Proc. Natl. Acad. Sci. USA., 95: 3117-3121. http://www.ncbi.nlm.nih.gov/pubmed/9501225

190.Cinque, P., L. Vago, M. Mengozzi, V. Torri, D. Ceresa and G. Poli, 1998. Elevated cerebrospinal fluid levels of monocyte chemotactic protein-1 correlate with HIV-1 encephalitis and local viral replication. AIDS, 12: 1327-1332. http://cat.inist.fr/?aModele $=$ afficheN\&cpsidt $=2341128$

191. Liu, X., M. Jana, S. Dasgupta, S. Koka, J. He, C. Wood and K. Pahan, 2002. Human immunodeficiency virus type 1 (HIV-1) tat induces nitric-oxide synthase in human astroglia. J. Biol. Chem., 277: 39312-39319. http://www.ncbi.nlm.nih.gov/pubmed/12167619

192. Fine, S.M., R.A. Angel, S.W. Perry, L.G. Epstein, J.D. Rothstein, S. Dewhurst and H.A. Gelbard, 1996. Tumor necrosis factor alpha inhibits glutamate uptake by primary human astrocytes. Implications for pathogenesis of HIV-1 dementia. J. Biol. Chem., 271: 15303-15306. http://www.ncbi.nlm.nih.gov/pubmed/8663435

193.Sevigny, J.J., S.M. Albert, M.P. McDermott, J.C. McArthur, N. Sacktor and K. Marder, 2004. Evaluation of HIV RNA and markers of immune activation as predictors of HIV-associated dementia. Neurology, 63: 2084-2090. http://www.neurology.org/cgi/content/abstract/63/1 $1 / 2084$

194.Nath, A. and J. Geiger, 1998. Neurobiological aspects of human immunodeficiency virus infection: Neurotoxic mechanisms. Prog. Neurobiol., 54: 19-33. http://www.ncbi.nlm.nih.gov/pubmed/9460791

195.Levin, M.C. and S. Jacobson, 1997. Cellular and humoral immune responses associated with HTLV-I associated myelopathy/tropical spastic paraparesis. Ann. NY. Acad. Sci., 835: 142-152. http://www.ncbi.nlm.nih.gov/pubmed/9616769 
196. Kubota, R., M. Nagai, T. Kawanishi, M. Osame and S. Jacobson, 2000. Increased HTLV type 1 tax specific CD8+ cells in HTLV type 1-asociated myelopathy/tropical spastic paraparesis: Correlation with HTLV type 1 proviral load. AIDS Res. Hum. Retroviruses, 16: 1705-1709. http://www.ncbi.nlm.nih.gov/pubmed/11080814

197.Daenke, S., A.G. Kermode, S.E. Hall, G. Taylor, J. Weber, S. Nightingale and C.R. Bangham, 1996. High activated and memory cytotoxic T-cell responses to HTLV-1 in healthy carriers and patients with tropical spastic paraparesis. Virology, 217: 139-146.

http://www.ncbi.nlm.nih.gov/pubmed/8599198

198. Jacobson, S., D.E. McFarlin, S. Robinson, R. Voskuhl, R. Martin, A. Brewah, A.J. Newell and S. Koenig, 1992. HTLV-I-specific cytotoxic T lymphocytes in the cerebrospinal fluid of patients with HTLV-Iassociated neurological disease. Ann. Neurol., 32: 651-657.

http://www.ncbi.nlm.nih.gov/pubmed/1449245

199.Umehara, F., S. Izumo, M. Nakagawa, A.T. Ronquillo, K. Takahashi, K. Matsumuro, E. Sato and M. Osame, 1993. Immunocytochemical analysis of the cellular infiltrate in the spinal cord lesions in HTLV-Iassociated myelopathy. J. Neuropathol. Exp. Neurol., 52: 424-430. http://www.ncbi.nlm.nih.gov/pubmed/8355031

200.Levin, M.C., S.M. Lee, F. Kalume, Y. Morcos, F.C. Dohan, Jr. and J.M. Stuart et al., 2002. Autoimmunity due to molecular mimicry as a cause of neurological disease. Nat. Med., 8: 509-513. http://www.ncbi.nlm.nih.gov/pubmed/11984596

201.Levin, M.C., S.M. Lee, Y. Morcos, J. Brady and J. Stuart, 2002. Cross-reactivity between immunodominant human T lymphotropic virus type I tax and neurons: Implications for molecular mimicry. J. Infect. Dis., 186: 1514-1517. http://www.ncbi.nlm.nih.gov/pubmed/12404172

202.Elovaara, I., U. Utz, S. Smith and S. Jacobson, 1995. Limited T cell receptor usage by HTLV-I tax-specific, HLA class I restricted cytotoxic $\mathrm{T}$ lymphocytes from patients with HTLV-I associated neurological disease. J. Neuroimmunol., 63: 47-53. http://www.ncbi.nlm.nih.gov/pubmed/8557824

203.Elovaara, I., S. Koenig, A.Y. Brewah, R.M. Woods, T. Lehky and S. Jacobson, 1993. High human T cell lymphotropic virus type 1 (HTLV-1)-specific precursor cytotoxic $\mathrm{T}$ lymphocyte frequencies in patients with HTLV-1-associated neurological disease. J. Exp. Med., 177: 1567-1573. http://cat.inist.fr/?aModele $=$ afficheN\&cpsidt $=4844$ 986
204.Muraro, P.A., K.P. Wandinger, B. Bielekova, B. Gran, A. Marques and R. Martin, 2003. Molecular tracking of antigen-specific $\mathrm{T}$ cell clones in neurological immune-mediated disorders. Brain, 126: 20-31. http://www.ncbi.nlm.nih.gov/pubmed/12477694

205.Liu, Y., K. Dole, J.R. Stanley, V. Richard, T.J. Rosol, L. Ratner, M. Lairmore and G. Feuer, 2002. Engraftment and tumorigenesis of HTLV-1 transformed $\mathrm{T}$ cell lines in SCID/bg and NOD/SCID mice. Leuk Res., 26: 561-567. http://www.ncbi.nlm.nih.gov/pubmed/12007504

206.Bangham, C.R., 2000. HTLV-1 infections. J. Clin. Pathol., 53: 581-586. http://jcp.bmj.com/cgi/content/abstract/53/8/581

207.Levin, M.C. and S. Jacobson, 1997. HTLV-I associated myelopathy/tropical spastic paraparesis (HAM/TSP): A chronic progressive neurologic disease associated with immunologically mediated damage to the central nervous system. J. Neurovirol., $\quad 3$ : 126-140. http://www.biomedexperts.com/Abstract.bme/9103 896/HTLV-Iassociated_myelopathy_tropical_spastic_parapares is_HAM_TSP

208.Jeffery, K.J., K. Usuku, S.E. Hall, W. Matsumoto, G.P. Taylor and C.R. Bangham et al., 1999. HLA alleles determine human T-lymphotropic virus-I (HTLV-I) proviral load and the risk of HTLV-Iassociated myelopathy. Proc. Natl. Acad. Sci. USA., 96: 3848-3853. http://www.ncbi.nlm.nih.gov/pubmed/10097126

209.Furukawa, Y., M. Yamashita, K. Usuku, S. Izumo, M. Nakagawa and M. Osame, 2000. Phylogenetic subgroups of human $\mathrm{T}$ cell lymphotropic virus (HTLV) type I in the tax gene and their association with different risks for HTLV-I-associated myelopathy/tropical spastic paraparesis. J. Infect. Dis., $\quad 182$ : 1343-1349. http://www.ncbi.nlm.nih.gov/pubmed/11010842

210.Barmak, K., E.W. Harhaj and B. Wigdahl, 2003. Mediators of central nervous system damage during the progression of human T-cell leukemia type I-associated myelopathy/tropical spastic paraparesis. J. Neuroviro., 9: 522-529. http://cat.inist.fr/?aModele $=$ afficheN\&cpsidt $=15172925$

211.Grassmann, R., S. Berchtold, I. Radant, M. Alt, B. Fleckenstein, J.G. Sodroski, W.A. Haseltine and U. Ramstedt, 1992. Role of human T-cell leukemia virus type $1 \mathrm{X}$ region proteins in immortalization of primary human lymphocytes in culture. J. Virol., 66: 4570-4575.

http://www.pubmedcentral.nih.gov/articlerender.fc gi? $\operatorname{artid}=241270$ 
212.Sodroski, J.G., C.A. Rosen and W.A. Haseltine, 1984. Trans-acting transcriptional activation of the long terminal repeat of human $\mathrm{T}$ lymphotropic viruses in infected cells. Science, 225: 381-385. http://www.ncbi.nlm.nih.gov/pubmed/6330891

213.Sodroski, J., C. Rosen, W.C. Goh, W. Haseltine, 1985. A transcriptional activator protein encoded by the $\mathrm{x}$-lor region of the human T-cell leukemia virus. $\quad$ Science, 228: 1430-1434. http://cat.inist.fr/?aModele $=$ afficheN\&cpsidt $=8572$ 669

214.Beimling, P. and K. Moelling, 1992. Direct interaction of CREB protein with 21 bp Taxresponse elements of HTLV-ILTR. Oncogene, 7: 257-262.

http://www.ncbi.nlm.nih.gov/pubmed/1532242

215.Paca-Uccaralertkun, S., L.J. Zhao, N. Adya, J.V. Cross, B.R. Cullen, I.M. Boros and C.Z. Giam, 1994. In vitro selection of DNA elements highly responsive to the human T-cell lymphotropic virus type I transcriptional activator, Tax. Mol. Cell Biol., 14: 456-462. http://www.pubmedcentral.nih.gov/articlerender.fc gi? artid=358395

216.Zhao, L.J. and C.Z. Giam, 1992. Human T-cell lymphotropic virus type I (HTLV-I) transcriptional activator, Tax, enhances CREB binding to HTLV-I 21-base-pair repeats by protein-protein interaction. Proc. Natl. Acad. Sci. USA., 89: 7070-7074. http://www.pubmedcentral.nih.gov/articlerender.fc gi artid $=49647$

217.Lenzmeier, B.A., H.A. Giebler and J.K. Nyborg, 1998. Human T-cell leukemia virus type 1 Tax requires direct access to DNA for recruitment of CREB binding protein to the viral promoter. Mol. Cell Biol., 18: 721-731. http://www.ncbi.nlm.nih.gov/pubmed/9447968

218.Adya, N. and C.Z. Giam, 1995. Distinct regions in human T-cell lymphotropic virus type I tax mediate interactions with activator protein CREB and basal transcription factors. J. Virol., 69: 1834-1841. http://www.pubmedcentral.nih.gov/articlerender.fc gi? artid $=188794$

219.Suzuki, T., H. Hirai, J. Fujisawa, T. Fujita and M. Yoshida, 1993. A trans-activator Tax of human T-cell leukemia virus type 1 binds to NF-kappa B p50 and Serum Response Factor (SRF) and associates with enhancer DNAs of the NF-kappa B site and CArG box. Oncogene, 8: 2391-2397. http://www.ncbi.nlm.nih.gov/pubmed/8361755

220.Azran, I., Y. Schavinsky-Khrapunsky and M. Aboud, 2004. Role of Tax protein in human T-cell leukemia virus type-I leukemogenicity. Retrovirology, 1: 20-20. http://www.ncbi.nlm.nih.gov/pubmed/15310405
221.Harrod, R., Y.L. Kuo, Y. Tang, Y. Yao, A. Vassilev, Y. Nakatani and C.Z. Giam, 2000. p300 and p300/cAMP-responsive element-binding protein associated factor interact with human T-cell lymphotropic virus type-1 Tax in a multi-histone acetyltransferase/activator-enhancer complex. J. Biol. Chem., 275: 20853-20860. http://www.ncbi.nlm.nih.gov/pubmed/10779504

222.Harrod, R., Y. Tang, C. Nicot, H.S. Lu, A. Vassilev, Y. Nakatani and C.Z. Giam, 1998. An exposed KID-like domain in human T-cell lymphotropic virus type 1 Tax is responsible for the recruitment of coactivators CBP/p300. Mol. Cell Biol., 18: 5052-5061.

http://cat.inist.fr/?aModele $=$ afficheN\&cpsidt $=1054$ 4243

223.Tie, F., N. Adya, W.C. Greene and C.Z. Giam, 1996. Interaction of the human T-lymphotropic virus type 1 Tax dimer with CREB and the viral 21-base-pair repeat. J. Virol., 70: 8368-8374. http://www.pubmedcentral.nih.gov/articlerender.fc gi?artid=190925

224.Arima, N., J.A. Molitor, M.R. Smith, J.H. Kim, Y. Daitoku and W.C. Greene, 1991. Human T-cell leukemia virus type I Tax induces expression of the Rel-related family of kappa B enhancer-binding proteins: evidence for a pretranslational component of regulation. J. Virol., 65: 6892-6899. http://jvi.asm.org/cgi/reprint/65/12/6892.pdf

225.Sun, S.C., J. Elwood, C. Beraud and W.C. Greene, 1994. Human T-cell leukemia virus type I Tax activation of NF-kappa B/Rel involves phosphorylation and degradation of I kappa B alpha and RelA (p65)-mediated induction of the crel gene. Mol. Cell Biol., 14: 7377-7384. http://mcb.asm.org/cgi/content/abstract/14/11/7377

226.Arias, J., A.S. Alberts, P. Brindle, F.X. Claret, T. Smeal, M. Karin, J. Feramisco and M. Montminy, 1994. Activation of cAMP and mitogen responsive genes relies on a common nuclear factor. Nature, 370: 226-229.

http://www.ncbi.nlm.nih.gov/pubmed/8028671

227. Chrivia, J.C., R.P. Kwok, N. Lamb, M. Hagiwara, M.R. Montminy and R.H. Goodman, 1993. Phosphorylated CREB binds specifically to the nuclear protein CBP. Nature, 365: 855-859. http://www.nature.com/nature/journal/v365/n6449/ $\mathrm{abs} / 365855 \mathrm{a} 0 . \mathrm{html}$

228.Gonzalez, G.A. and M.R. Montminy, 1989. Cyclic AMP stimulates somatostatin gene transcription by phosphorylation of CREB at serine 133. Cell, 59: 675-680.

http://www.ncbi.nlm.nih.gov/pubmed/2573431 
229.Zhao, L.J. and C.Z. Giam, 1991. Interaction of the human T-cell lymphotrophic virus type I (HTLV-I) transcriptional activator Tax with cellular factors that bind specifically to the 21-base-pair repeats in the HTLV-I enhancer. Proc. Natl. Acad. Sci. USA., 88: 11445-11449.

http://www.pubmedcentral.nih.gov/articlerender.fc gi? artid=53152

230.Feuer, G., J.K. Fraser, J.A. Zack, F. Lee, R. Feuer and I.S. Chen, 1996. Human T-cell leukemia virus infection of human hematopoietic progenitor cells: Maintenance of virus infection during differentiation in vitro and in vivo. J. Virol., 70: 4038-4044. http://jvi.asm.org/cgi/content/abstract/70/6/4038

231.Mikovits, J., F. Ruscetti, W. Zhu, R. Bagni, D. Dorjsuren and R. Shoemaker, 2001. Potential cellular signatures of viral infections in human hematopoietic cells. Dis. Marker., 17: 173-178. http://cat.inist.fr/?aModele=afficheN\&cpsidt=14155476

232.Hoffman, P.M., S. Dhib-Jalbut, J.A. Mikovits and D.S. Robbins et al., 1992. Human T-cell leukemia virus type I infection of monocytes and microglial cells in primary human cultures. Proc. Natl. Acad. Sci. USA., 89: 11784-11788.

http://www.pubmedcentral.nih.gov/articlerender.fc gi? artid=50641

233.Szymocha, R., C. Brisson, A. Bernard, H. Akaoka, M.F. Belin and P. Giraudon, 2000. Long-term effects of HTLV-1 on brain astrocytes: Sustained expression of Tax-1 associated with synthesis of inflammatory mediators. J. Neurovirol., 6: 350-357.

http://www.aegis.com/aidsline/2000/nov/A00B025 0.html

234.Hirayama, M., T. Miyadai, T. Yokochi, K. Sato, T. Kubota, M. Iidaand N. Fujiki, 1988. Infection of human T-lymphotropic virus type I to astrocytes in vitro with induction of the class II major histocompatibility complex. Neurosci. Lett., 92: 34-39. http://www.ncbi.nlm.nih.gov/pubmed/3185977

235. Yamada, M., K. Watabe, T. Saida and S.U. Kim, 1991. Increased susceptibility of human fetal astrocytes to human T-lymphotropic virus type I in culture. J. Neuropathol. Exp. Neurol., 50: 97-107. http://cat.inist.fr/?aModele $=$ afficheN\&cpsidt $=4505407$

236.Mendez, E., T. Kawanishi, K. Clemens, H. Siomi and S.S. Soldan et al., 1997. Astrocyte-specific expression of human T-cell lymphotropic virus type 1 (HTLV-1) Tax: Induction of tumor necrosis factor alpha and susceptibility to lysis by CD8+ HTLV-1-specific cytotoxic T cells. J. Virol., 71: 9143-9149. http://cat.inist.fr/?aModele $=$ afficheN\&cpsidt $=10858480$
237.Koyanagi, Y., Y. Itoyama, N. Nakamura, K. Takamatsu, J. Kira, T. Iwamasa, I. Goto and $\mathrm{N}$. Yamamoto, 1993. In vivo infection of human Tcell leukemia virus type I in non-T cells. Virology, 196: 25-33.

http://www.ncbi.nlm.nih.gov/pubmed/8356797

238.Quiterio, S., C. Grant, T.H. Hogan, F.C. Krebs and B. Wigdahl, 2003. C/EBP-and Tat-mediated activation of the HIV-1 LTR in CD34+ hematopoietic progenitor cells. Biomed. Pharmacother., 57: 49-56. http://www.ncbi.nlm.nih.gov/pubmed/12642037

239.Hivin, P., G. Gaudray, C. Devaux and J.M. Mesnard, 2004. Interaction between $\mathrm{C} / \mathrm{EBP}$ beta and Tax down-regulates human T-cell leukemia virus type I transcription. Virology, 318: 556-565. http://www.ncbi.nlm.nih.gov/pubmed/14972524

240.Grant, C., M. Nonnemacher, P. Jain, D. Pandya, B. Irish, S.C. Williams and B. Wigdahl, 2006. CCAAT/enhancer-binding proteins modulate human $\mathrm{T}$ cell leukemia virus type 1 long terminal repeat activation. Virology, 348: 354-369. http://www.ncbi.nlm.nih.gov/pubmed/16458341

241.Grant, C., P. Jain, M. Nonnemacher, K.E. Flaig, B. Irish and B. Wigdahl et al., 2006. AP-1-directed human $\mathrm{T}$ cell leukemia virus type 1 viral gene expression during monocytic differentiation. J. Leukoc Biol., 80: 640-650. http://www.jleukbio.org/cgi/content/abstract/80/3/640

242.Wessner, R., J. Yao and B. Wigdahl, 1997. Sp family members preferentially interact with the promoter proximal repeat within the HTLV-I enhancer. Leukemia, 11: 10-13. http://www.ncbi.nlm.nih.gov/pubmed/9209281

243.Barnhart, M.K., L.M. Connor and S.J. Marriott, 1997. Function of the human T-cell leukemia virus type 121 -base-pair repeats in basal transcription. J. Virol., 71: 337-344. http://www.pubmedcentral.nih.gov/articlerender.fc gi?artid=191056

244.Jiang, H., H. Lu, R.L. Schiltz, C.A. Pise-Masison, V.V. Ogryzko, Y. Nakatani and J.N. Brady, 1999. PCAF interacts with tax and stimulates tax transactivation in a histone acetyltransferaseindependent manner. Mol. Cell. Biol., 19: 8136-8145. http://www.ncbi.nlm.nih.gov/pubmed/10567539

245.Kashanchi, F., J.F. Duvall, R.P. Kwok, J.R. Lundblad, R.H. Goodman and J.N. Brady, 1998. The coactivator CBP stimulates human Tcell lymphotrophic virus type I Tax transactivation in vitro. J. Biol. Chem., 273: 34646-34652.

http://www.ncbi.nlm.nih.gov/pubmed/9852138 
246.Okada, M. and K.T. Jeang, 2002. Differential requirements for activation of integrated and transiently transfected human T-cell leukemia virus type 1 long terminal repeat. J. Virol., 76: 12564-12573. http://www.ncbi.nlm.nih.gov/pubmed/12438582

247.Alefantis, T., P. Jain, J. Ahuja, K. Mostoller and B. Wigdahl, 2005. HTLV-1 Tax nucleocytoplasmic shuttling, interaction with the secretory pathway, extracellular signaling and implications for neurologic disease. J. Biomed. Sci., 12: 961-974. http://cat.inist.fr/?aModele $=$ afficheN\&cpsidt $=1776$ 2490

248. Smith, M.R. and W.C. Greene, 1992. Characterization of a novel nuclear localization signal in the HTLV-I tax transactivator protein. Virology, 187: 316-320. http://www.ncbi.nlm.nih.gov/pubmed/1736534

249.Gitlin, S.D., P.F. Lindholm, S.J. Marriott and J.N. Brady, 1991. Transdominant human T-cell lymphotropic virus type I TAX1 mutant that fails to localize to the nucleus. J. Virol., 65: 2612-2621. http://www.pubmedcentral.nih.gov/articlerender.fc gi? artid=240619

250.Cartier, L. and E. Ramirez, 2005. Presence of HTLV-I Tax protein in cerebrospinal fluid from HAM/TSP patients. Arch. Virol., 150: 743-753. DOI: 10.1007/s00705-004-0443-3

251.Bex, F., K. Murphy, R. Wattiez, A. Burny and R. Gaynor, 1999. Phosphorylation of the human Tcell leukemia virus type 1 transactivator tax on adjacent serine residues is critical for tax activation. J. Virol., 73: 738-745. http://jvi.asm.org/cgi/content/abstract/73/1/738

252.Fontes, J., J. Strawhecker, N. Bills, R. Lewis and S. Hinrichs, 1993. Phorbol esters modulate the phosphorylation of human T-cell leukemia virus type I Tax. J. Virol., 67: 4436-4441. http://www.pubmedcentral.nih.gov/articlerender.fcgi ?artid $=237821$

253.Lindholm, P.F., S.J. Marriott, S.D. Gitlin, C.A. Bohan and J.N. Brady, 1990. Induction of nuclear NF-kappa B DNA binding activity after exposure of lymphoid cells to soluble tax 1 protein. New Biol., 2: 1034-1043. http://www.ncbi.nlm.nih.gov/pubmed/2101630

254.Alefantis, T., K. Mostoller, P. Jain, E. Harhaj, C. Grant and B. Wigdahl, 2005. Secretion of the human $\mathrm{T}$ cell leukemia virus type I transactivator protein tax. J. Biol. Chem., 280: 17353-17362. http://www.ncbi.nlm.nih.gov/pubmed/15659397

255.Lippincott-Schwartz, J., C.L. Smith, 1997. Insights into secretory and endocytic membrane traffic using green fluorescent protein chimeras. Curr. Opin. Neurobiol., $\quad$ 7: 631-639. http://www.ncbi.nlm.nih.gov/pubmed/9384543
256.Lippincott-Schwartz, J., T.H. Roberts and K. Hirschberg, 2000. Secretory protein trafficking and organelle dynamics in living cells. Ann. Rev. Cell Dev. Biol., 16: 557-589. http://www.ncbi.nlm.nih.gov/pubmed/11031247

257.Bannykh, S.I. and W.E. Balch, 1998. Selective transport of cargo between the endoplasmic reticulum and Golgi compartments. Histochem Cell Biol., $\quad$ 109: 463-475. http://www.ncbi.nlm.nih.gov/pubmed/9681628

258.Bannykh, S.I., N. Nishimura and W.E. Balch, 1998. Getting into the Golgi. Trend. Cell Biol., 8: 21-25. http://www.ncbi.nlm.nih.gov/pubmed/9695803

259.Nishimura, N., S. Bannykh, S. Slabough, J. Matteson, Y. Altschuler, K. Hahn and W.E. Balch, 1999. A diacidic (DXE) code directs concentration of cargo during export from the endoplasmic reticulum. J. Biol. Chem., 274: 15937-15946. http://www.ncbi.nlm.nih.gov/pubmed/10336500

260.Sevier, C.S., O.A. Weisz, M. Davis and C.E. Machamer, 2000. Efficient export of the vesicular stomatitis virus $G$ protein from the endoplasmic reticulum requires a signal in the cytoplasmic tail that includes both tyrosine-based and di-acidic motifs. Mol. Biol. Cell, 11: 13-22. http://www.molbiolcell.org/cgi/content/abstract/11/1/13

261.Jain, P., K. Mostoller, K.E. Flaig, J. Ahuja, V. Lepoutre and B. Wigdahl et al., 2007. Identification of human $\mathrm{T}$ cell leukemia virus type 1 tax amino acid signals and cellular factors involved in secretion of the viral oncoprotein. J. Biol. Chem., 282: 34581-34593. http://www.jbc.org/cgi/content/abstract/282/47/34581

262.Alefantis, T., K.E. Flaig, B. Wigdahl and P. Jain, 2007. Interaction of HTLV-1 Tax protein with calreticulin: Implications for Tax nuclear export and secretion. Biomed. Pharmacother, 61: 194-200. http://www.pubmedcentral.nih.gov/articlerender.fc gi? artid=2043122

263.Cowan, E.P., R.K. Alexander, S. Daniel, F. Kashanchi and J.N. Brady, 1997. Induction of tumor necrosis factor alpha in human neuronal cells by extracellular human T-cell lymphotropic virus type 1 Tax. J. Virol., 71: 6982-6989. http://jvi.asm.org/cgi/content/abstract/71/9/6982

264.Brady, J.N., 1992. Extracellular Tax1 protein stimulates NF-kB and expression of NF-kBresponsive Ig kappa and TNF beta genes in lymphoid cells. AIDS Res. Hum. Retroviruses, 8: 724-727. http://www.ncbi.nlm.nih.gov/pubmed/1515222?do $\mathrm{pt}=\mathrm{Abstract}$ 
265.Selmaj, K.W. and C.S. Raine, 1988. Tumor necrosis factor mediates myelin and oligodendrocyte damage in vitro. Ann. Neurol., 23: 339-346.

http://www.ncbi.nlm.nih.gov/pubmed/3132891

266.Dhib-Jalbut, S., P.M. Hoffman, T. Yamabe, D. Sun, J. Xia and F.W. Ruscetti et al., 1994. Extracellular human T-cell lymphotropic virus type I Tax protein induces cytokine production in adult human microglial cells. Ann. Neurol., 36: 787-790. http://www.ncbi.nlm.nih.gov/pubmed/7979225

267.Ali, A., S. Patterson, K. Cruickshank, P. Rudge, A.G. Dalgleish and S.C. Knight, 1993. Dendritic cells infected in vitro with human $\mathrm{T}$ cell leukaemia/lymphoma virus type-1 (HTLV-1); enhanced lymphocytic proliferation and tropical spastic paraparesis. Clin. Exp. Immunol., 94: 32-37. http://www.pubmedcentral.nih.gov/articlerender.fc gi? $\operatorname{artid}=1534377$

268.Makino, M., S. Wakamatsu, S. Shimokubo, N. Arima and M. Baba, 2000. Production of functionally deficient dendritic cells from HTLV-I-infected monocytes: Implications for the dendritic cell defect in adult $\mathrm{T}$ cell leukemia. Virology, 274: 140-148.

http://linkinghub.elsevier.com/retrieve/pii/S004268 2200904458

269.Macatonia, S.E., J.K. Cruickshank, P. Rudge and S.C. Knight, 1992. Dendritic cells from patients with tropical spastic paraparesis are infected with HTLV-1 and stimulate autologous lymphocyte proliferation. AIDS, Res. Hum. Retroviruses, 8: 1699-1706.

http://cat.inist.fr/?aModele $=$ afficheN\&cpsidt $=4437$ 342

270.Makino, M., S. Shimokubo, S.I. Wakamatsu, S. Izumo and M. Baba, 1999. The role of human Tlymphotropic virus type 1 (HTLV-1)-infected dendritic cells in the development of HTLV-1associated myelopathy/tropical spastic paraparesis. J. Virol., 73: 4575-4581. http://jvi.asm.org/cgi/content/abstract/73/6/4575?m axtoshow $=\&$ HITS $=10 \&$ hits $=10 \&$ RESULTFORM $\mathrm{AT}=\&$ fulltext $=\% \mathrm{C} 2 \% \mathrm{~B} 5 \mathrm{~g} \&$ searchid $=1 \&$ FIRSTIN DEX $=760 \&$ resourcetype $=$ HWFIG
271.Mostoller, K., C.C. Norbury, P. Jain and B. Wigdahl, 2004. Human T-cell leukemia virus type I Tax induces the expression of dendritic cell markers associated with maturation and activation. J. Neurovirol., 10: 358-371. http://www.ncbi.nlm.nih.gov/pubmed/15765807

272.Ahuja, J., K. Kampani, S. Datta, B. Wigdahl, K.E. Flaig and P. Jain, 2006. Use of human antigen presenting cell gene array profiling to examine the effect of human T-cell leukemia virus type 1 Tax on primary human dendritic cells. J. Neurovirol., 12: 47-59.

http://cat.inist.fr/?aModele=afficheN\&cpsidt=1782 4988

273. Ahuja, J., V. Lepoutre, B. Wigdahl, Z.K. Khan and P. Jain, 2007. Induction of pro-inflammatory cytokines by human T-cell leukemia virus type-1 Tax protein as determined by multiplexed cytokine protein array analyses of human dendritic cells. Biomed. Pharmacother, 61: 1-8. http://www.pubmedcentral.nih.gov/articlerender.fc gi? artid=2043123

274.Jain, P., J. Ahuja, Z.K. Khan, S. Shimizu, O. Meucci, S.R. Jennings and B. Wigdahl, 2007. Modulation of dendritic cell maturation and function by the Tax protein of human $\mathrm{T}$ cell leukemia virus type 1. J. Leukoc Biol., 82: 44-56. http://www.ncbi.nlm.nih.gov/pubmed/17442856

275.Sacktor, N., M.P. McDermott, K. Marder, G. Schifitto, O.A. Selnes and L. Epstein et al., 2002. HIV-associated cognitive impairment before and after the advent of combination therapy. $\mathrm{J}$. Neurovirol., $\quad 8$ : 136-142. http://www.ncbi.nlm.nih.gov/pubmed/11935465

276.Letendre, S.L., J.A. McCutchan, M.E. Childers, S.P. Woods, D. Lazzaretto and R.J. Ellis et al., 2004. Enhancing antiretroviral therapy for human immunodeficiency virus cognitive disorders. Ann. Neurol., 56: 416-423. http://www.ncbi.nlm.nih.gov/pubmed/15349869 